\title{
G Protein-Coupled Receptors Mediate a Fast Excitatory Postsynaptic Current in CA3 Pyramidal Neurons in Hippocampal Slices
}

\author{
Lucas D. Pozzo Miller, Jeffrey J. Petrozzino, and John A. Connor \\ Roche Institute of Molecular Biology, Roche Research Center, Nutley, New Jersey 07110-1199
}

Synaptic activation in the presence of competitive (D,LAPV, CNQX) and noncompetitive (MK-801, GYKI-52466) ionotropic glutamate receptor antagonists induced fast (10$90 \%$ rise time of $15-30 \mathrm{msec}$ ) postsynaptic responses in CA3 pyramidal neurons from acute and cultured hippocampal slices. Postsynaptic currents were studied extensively in slice cultures, and displayed a linear current-voltage relationship, with a reversal potential between $0 \mathrm{mV}$ and +10 $\mathrm{mV}$, suggesting the activation of a nonselective cationic conductance. Inhibition of the GTPase cycle by intracellular perfusion with the nonhydrolyzable analog of GDP, GDP $\beta S$, blocked the fast postsynaptic responses evoked in ionotropic antagonists, as well as baclofen-mediated outward $\mathrm{K}^{+}$currents, known to be mediated by $\mathrm{G}$ proteincoupled $\mathrm{GABA}_{B}$ receptors. Intracellular perfusion with GDP $\beta S$ did not affect the AMPA/kainate component of the synaptic currents. Irreversible activation of $\mathrm{G}$ proteins by intracellular perfusion with the nonhydrolyzable analog of GTP, GMP-PNP, occluded the baclofen responses, and evoked an inward current, consistent with the synaptically mediated conductance. Incubation of the slice cultures in pertussis toxin for $\mathbf{7 2} \mathrm{hr}$ blocked baclofen-induced outward $\mathrm{K}^{+}$currents, while the fast postsynaptic currents remained. The metabotropic glutamate receptor (mGluR) agonists 1S,3R-ACPD and 1S,3S-ACPD induced an inward current in the presence of the ionotropic antagonists, and occluded the fast EPSCs. The fast EPSCs were partially blocked by the mGluR antagonlsts L-AP3 and (+)MCPG, but there was differential antagonist sensitivity in two pathways stimulated (CA3 stratum radiatum vs CA3 stratum oriens). These data suggest that fast postsynaptic responses evoked in the presence of ionotropic glutamate receptor antagonists are mediated by $\mathrm{G}$ protein-coupled mGluRs linked to nonselective cationic channels.

[Key words: intracellular perfusion, ionotropic glutamate receptor, GDP $\beta S$, metabotropic glutamate receptor, organotypic slice culture, whole-cell voltage clamp]

Metabotropic glutamate receptors (mGluRs) in general do not directly gate ion flow, but instead are coupled to ion channels through a variety of second messenger systems via guanosine-

\footnotetext{
Received May 8, 1995; revised Aug. 11, 1995; accepted Aug. 17, 1995.

We thank Dr. L. Birnbaumer (UCLA) for helpful discussions, Dr. J. Drejer (NeuroSearch, Denmark) for kindly providing NS-102, L. Verselis for tissue culture work, and S. Sun for technical assistance.

Correspondence should be addressed to Lucas D. Pozzo Miller, Ph.D., Laburatory of Neurobiology, NINDS, NIH, Building 36, 2A-18, Bethesda, MD 20892.

Copyright (C) 1995 Society for Neuroscience $0270-6474 / 95 / 158320-11 \$ 05.00 / 0$
}

5 '-triphosphate (GTP)-binding proteins (G proteins; for review, see Schoepp and Conn, 1993). To date, eight subtypes of $\mathrm{m}$ GluRs have been isolated by expression cloning. The cloned receptors $\mathrm{mGluR} 1$ and $\mathrm{mGluR5}$ are coupled to stimulation of phosphoinositide (PI) hydrolysis via phospholipase $\mathrm{C}$, and are more sensitive to quisqualic acid than to $1 S R, 3 R S$-aminocyclopentane-1,3-dicarboxylic acid (ACPD; Abe et al., 1992; Aramori and Nakanishi, 1992). mGluR 1 is also coupled to stimulation of phospholipase $\mathrm{A}_{2}$ and adenyl cyclase (Aramori and Nakanishi, 1992). The cloned receptors mGluR2 and mGluR3 are more sensitive to ACPD than to quisqualic acid and inhibit forskolinstimulated cyclic adenosine-3',5'-monophosphate (cAMP) formation (Tanabe et al., 1992, 1993). mGluR4, mGluR6, mGluR7, and mGluR 8 are also negatively coupled to adenyl cyclase but they are more sensitive to 2-amino-4-phosphonobutyrate (AP4; Nakanishi, 1992; Nakajima et al., 1993; Okamoto et al., 1994; Saugstad et al., 1994; Duvoisin et al., 1995).

Various effects of mGluR agonists on neuronal membrane ion fluxes include: blockade of several $\mathrm{K}^{+}$currents (Curry et al., 1987; Stratton et al., 1989; Charpak et al., 1990; Ishida et al., 1990; Stratton et al., 1990; Charpak and Gähwiler, 1991; Salt and Eaton, 1991; Guérineau et al., 1994); inhibition of $\mathrm{Ca}^{2+}$ dependent and voltage-gated $\mathrm{K}^{+}$currents (Stratton et al., 1989; Baskys et al., 1990; Charpak et al., 1990; Stratton et al., 1990); activation of $\mathrm{K}^{\prime}$ currents (Shirasaki et al., 1994); inhibition of $\mathrm{Ca}^{2+}$ currents (Lester and Jahr, 1990; Swartz and Bean, 1992; Trombley and Westbrook, 1992; Sahara and Westbrook, 1993); and activation of nonselective cationic conductances (Crépel et al., 1994; Guérineau et al., 1995). mGluRs has been implicated in the potentiation of $N$-methyl-D-aspartate (NMDA)- and $\alpha$-amino-3-hydroxy-5-methylisoxazole propionic acid (AMPA)-activated currents (Aniksztejn et al., 1991; Harvey et al., 1991). Their effects on synaptic transmission and plasticity include long-term depression of GABAergic inhibitory postsynaptic potentials (IPSPs; Liu et al., 1993); potentiation of spontaneous GABA $_{\mathrm{A}}$ IPSPs (Miles and Poncer, 1993); presynaptic inhibition of synaptic transmission (Baskys and Malenka, 1991; Pacelli and Kelso, 1991; Pook et al., 1992); either induction or augmentation of long-term potentiation (Otani and Ben-Ari, 1991; Bortolotto and Collingridge, 1992, 1993; McGuinness et al., 1992; Zheng and Gallagher, 1992; Bashir et al., 1993a; Collins and Davies, 1993; Petrozzino and Connor, 1994); and induction of long-term depression (Linden and Connor, 1991; Linden et al., 1991; Bashir et al., 1993b; Yang et al., 1994).

We report here that synaptic activation of CA3 neurons in hippocampal slices in the presence of competitive and noncompetitive ionotropic glutamate receptor antagonists induces a fast 
excitatory postsynaptic current that is sensitive to the disruption of the GTPase cycle using a nonhydrolyzable analog of guanosine-5'-diphosphate (GDP), as well as to the mGluR antagonists L-AP3 and (+)MCPG. Furthermore, selective mGluR agonists activated a similar conductance, and occluded the evoked postsynaptic currents. The findings suggest that fast postsynaptic currents are mediated by an interaction between $G$ protein-coupled metabotropic glutamate receptors and nonselective cationic channels.

Preliminary observations have been reported (Pozzo Miller et al., 1993a, 1994b).

\section{Materials and Methods}

The preparation of hippocampal slice cultures followed techniques originally described by Gähwiler (1981) and Stoppini et al. (1991), with minor modifications (Pozzo Miller et al., 1993b). Briefly, 6-8-d-old Sprague-Dawley rat pups (Harlan, Frederick, MD) were decapitated, and the brains aseptically removed and placed in sterile Gey's Balanced Salt Solution, supplemented with $36 \mathrm{mM}$ D-glucose. Hippocampi were dissected out, embedded in sterile agar on plastic coverslips, and cut into $\approx 350-\mu \mathrm{m}$-thick transverse slices with a Mcllwain tissue chopper (Brinkmann, Westbury, NY). Alternatively, hippocampi were dissected out and immediately sliced without embedding at $\simeq 400 \mu \mathrm{m}$ thickness using a wire slicer (Katz, 1987; Caltech, Pasadena, CA). Slices were incubated for $30 \mathrm{~min}$ in Gey's Balanced Salt Solution supplemented with $36 \mathrm{~mm}$ D-glucose at $4^{\circ} \mathrm{C}$, mounted individually on Millicell-CM tissue culture inserts (Millipore, Bedford, MA), and then placed in a $5 \% \mathrm{CO}_{2}, 36^{\circ} \mathrm{C}, 95 \%$ relative humidity incubator (Forma Scientific Inc., Marietta, $\mathrm{OH}$ ). The slice cultures were fed twice a week with a media containing Minimum Essential Medium (50\%), Earle's Balanced Salt Solution $(25 \%)$ and heat-inactivated horse serum (or defined equine serum from HyClone Labs Inc, Logan, UT; 25\%), supplemented with $1 \mathrm{~mm}$ L-glutamine, and $36 \mathrm{~mm}$ D-glucose. Tissue culture reagents were obtained from GIBCO-BRL (Gaithersburg, MD). Hippocampal slices were maintained in the interface of medium and $\mathrm{CO}_{2}$ atmosphere, by allowing the culture media to form a thin film over the tissue slices, without covering them at any time. No antimitotic administration, or irradiation procedures were used to reduce non-neuronal cell proliferation.

To test the involvement of $G_{0}$ or $G_{i}$ subtypes of $G$ proteins in the mediation of the evoked EPSCs, slice cultures were treated with 500 $\mathrm{ng} / \mathrm{ml}$ pertussis toxin (PTX; Calbiochem, La Jolla, CA) for $24 \mathrm{hr}$, followed by replacement with medium containing fresh PTX for an additional $24 \mathrm{hr}$ period.

For intracellular recording the Millicell-CM plastic inserts with 5-10 d in vitro slice cultures were transferred to an immersion-type slice chamber (volume $\simeq 3 \mathrm{ml}$ ), and continuously perfused $(2-4 \mathrm{ml} / \mathrm{min}$ ) with saline at room temperature $\left(23-24^{\circ} \mathrm{C}\right.$ ), containing (in $\left.\mathrm{mm}\right) \mathrm{NaCl}$, 124; $\mathrm{KCl}, 2 ; \mathrm{MgSO}_{4}, 1.3$ (or 4); $\mathrm{KH}_{2} \mathrm{PO}_{4}, 1.24 ; \mathrm{NaHCO}_{3}, 17.6 ; \mathrm{CaCl}_{2}$, 2.5 (or 4); D-glucose, 10 ; equilibrated with $95 \% \quad 0_{2} / 5 \% \mathrm{CO}_{2} ; 310-320$ mOsm. Muscarinic and nicotinic cholinergic, GABAergic, and glutamatergic receptor agonists and antagonists were applied by perfusion with the extracellular recording solution. D,L-APV, kynurenic acid, atropine, baclofen, and picrotoxin were purchased from Sigma (St. Louis, MO); tubocurarine, CNQX, and GYKI-52466 were obtained from RBI (Natick, MA); L-AP3 was obtained from either RBI or Tocris Neuramin (Buckhurst Hill, UK); 1S,3R-ACPD, 1S,3S-ACPD, AMOA, (+)MCPG, and $(R, S) \mathrm{MCPG}$ from Tocris; and nimodipine from Miles Inc. (West Haven, CT). MK-801 was provided by Hoffmann-LaRoche Inc. (Nutley, NJ). NS-102, was kindly provided by Dr. J. Drejer (NeuroSearch Gløstrup, Denmark).

Using a $40 \times(0.75 \mathrm{NA})$ water immersion objective (Achroplan, Zeiss, Thornwood, NY) in an fixed stage upright microscope (Zeiss) superfi cial neuronal cell bodies were clearly identifiable under bright-field in all the hippocampal regions. Whole-cell recordings were made using unpolished patch electrodes pulled from borosilicate thin-wall glass (WPI, Sarasota, FL) in a two-stage pipette puller (PP-83, Narishige, Sea Cliff, $\mathrm{NY}$ ) and containing (in $\mathrm{mM}$ ) $\mathrm{Cs}^{+}$-gluconate (or $\mathrm{K}^{+}$-gluconate), 120; Na-HEPES, 10; CsCl (or KCl), 1\% 5 ; NaCl, 10; EGTA, 0.2; MgATP, 2; Na-GTP, 0.2; 280-290 mOsm; pH 7.2 (final resistance of these electrodes was $8-10 \mathrm{M} \Omega$ ). Under visual control, the most superficial CA3 pyramidal neurons were approached with the patch electrodes at the level of the cell body, while applying positive pressure to the barrel of the pipettes. High-resistance seals $(>1 \mathrm{G} \Omega$ ) were formed by advancing the electrodes against the plasma membrane until they just deformed the membrane, and then applying transient negative pressure. Whole-cell access was obtained by rupturing the plasma membrane under the pipette tip with gentle continuous negative pressure. Alternatively, CA3 pyramidal neurons were impaled with sharp microelectrodes, whose tips contained $3 \mathrm{M} \mathrm{KCl}$ or $\mathrm{K}^{+}$-acetate, and had a final resistance of $80-100 \mathrm{M} \Omega$ Pyramidal neurons were identified by their morphology after intracellular dialysis with $500 \mu \mathrm{M}$ mag-fura 2 (pentapotassium salt; Molecular Probes, Eugene, OR; see below).

CA3 pyramidal cells were voltage clamped in the discontinuous, single-electrode mode of the Axoclamp-2A (Axon Instruments, Foster City, CA) with a sampling frequency of $6-8 \mathrm{kHz}$. The gain of the voltage-clamp was set between 5 and $10 \mathrm{nA} / \mathrm{mV}$, time constant $20 \mathrm{msec}$. The voltage signal from the electrode was continually monitored in a separate oscilloscope to ensure optimal performance of the voltage clamp. CA3 cells were clamped between -70 and $-90 \mathrm{mV}$, and had input resistances of $212.29 \pm 11.95 \mathrm{M} \Omega(n-34)$.

Some cells were dialysed with the $\mathrm{Ca}^{2+}$ chelator BAPTA (potassium salt, $20 \mathrm{~mm}$; Molecular Probes). Intracellular diffusion of BAPTA was assessed by monitoring the low-affinity fluorescent $\mathrm{Ca}^{2}$ indicator Indagfura 2 (potassium salt, $500 \mu \mathrm{M}$; Molecular Probes) included in the barrel of the patch electrodes. Indicator fluorescence was elicited by epi-illumination via fiber optics with light from a mercury arc lamp passed through a $380 \mathrm{~nm}$ filter. Cells were imaged from the top surface of the slice cultures. Digitized images were taken with a cooled CCD camera system (CH250, Photometrics, Tucson, AZ) with a Macintosh IIci (Apple, Cupertino, CA) controlling image acquisition and display systems. Since no indicator (or BAPTA) was included at the tip of the patch electrode, it took about 10 min for mag-fura 2 fluorescence to reach detectable levels at the tip of the patch pipette and soma. After approximately 20-30 min of whole-cell access, mag-fura 2 fluorescence equilibrated at the soma and proximal dendrites, while it took about $1 \mathrm{hr}$ for the indicator fluorescence to equilibrate at the more distal fine dendritic processes.

In experiments designed to obtain the current-voltage relationship of the evoked EPSCs, QX-314 (2-10 mM; RBI) was included in the internal solution. To test the involvement of $G$ proteins in the evoked EPSCs, the nonhydrolyzable analog of GDP, GDP $3 S$ (500 $\mu \mathrm{M}$; Boehringer Mannheim, Indianapolis, IN), or the nonhydrolyzable analog of GTP, GMP-PNP ( $250 \mu \mathrm{M}$; Boehringer Mannheim), was introduced into the electrodes after whole-cell access was achieved with control solution, via a patch pipette perfusion system $\left(2 \mathrm{PK}^{+}, \Lambda\right.$ dams \& List $\Lambda$ ss., Westbury, NY). A quartz capillary, flame pulled and cut to around 30 $\mu \mathrm{m}$ i.d., was positioned at $\simeq 100 \mu \mathrm{m}$ from the electrode tip and connected through a polyethylene line that led out of the electrode holder via a separate port. The polyethylene line connected to a vial containing the intracellular solution to be exchanged by perfusion. Finally, a pressure transducer was used to apply $15-20 \mathrm{~mm} \mathrm{Hg}$ of negative pressure to the barrel of the patch electrode, drawing the solution from the quartz capillary into the electrode tip.

Anatomical terms and divisions follow original descriptions by Lorente de Nó (1934). Presynaptic fibers were stimulated using a bipolar stainless steel electrode (FHC, Brunswich, ME) positioned over stratum granulosum of the dentate gyrus, or in the apical dendritic region of $\mathrm{CA} 3$, or in stratum oriens of $\mathrm{CA} 3$ (toward the CA1 region). Single shocks of $100 \mu \mathrm{sec}$ were delivered by a stimulus isolator/constant current unit (ISO-Flex, AMPI, Jerusalem, Israel) at a intensity of $10 \mu \mathrm{A}$ to $2 \mathrm{~mA}$ at $0.25-0.5 \mathrm{~Hz}$

Additional experiments were performed on CA3 neurons in $300 \mu \mathrm{m}$ thick, transverse slices of adult rat (180-220 gm) hippocampus prepared using a vibratome (Ted Pella Inc., Redding, CA) and standard procedures. Rats were anesthetized by intramuscular injection of a mixture of ketamine $(87 \mathrm{mg} / \mathrm{kg})$ and xylazine $(13 \mathrm{mg} / \mathrm{kg})$. Slices were placed in an interface type recording chamber and perfused with saline $\left(22-24^{\circ} \mathrm{C}\right)$ containing (in mM) NaCl, $124 ; \mathrm{KCl}, 2 ; \mathrm{MgSO}_{4}, 3.0 ; \mathrm{KH}_{2} \mathrm{PO}_{4}, 1.25$; $\mathrm{NaHCO}_{3}, 18 ; \mathrm{CaCl}_{2}, 3.0$; glucose, 10 ; equilibrated with $95 \% \mathrm{O}_{2} / 5 \%$ $\mathrm{CO}_{2}$ (pH 7.4). CA3 ncurons were impaled with 100-150 $\mathrm{M} \Omega$ microelectrodes containing $3 \mathrm{M} \mathrm{CsCl}$ and voltage clamped using the discontinuous mode of an Axoclamp-2A amplifier (Axon Instruments) with a switching frequency of $6-7 \mathrm{kHz}$. Stimuli of $100 \mu \mathrm{sec}$ duration were applied through a bipolar stainless steel electrode (FHC) placed in CA3 stratum lucidum via a stimulus isolator/constant current unit (ISOFlex, AMPI).

All data are expressed as mean \pm standard error, while statistical 
Figure 1. A, EPSCs after single shock $(100 \mu \mathrm{sec})$ stimulation of dentate gyrus stratum granulosum: effect of the noncompetitive antagonist GYKI-52466 on EPSCs at high stimulus strength. Top trace, Control bath saline (picrotoxin, $50 \mu \mathrm{M})$. Stimulus intensity at $180 \mu \mathrm{A}$. Middle trace, Ionotropic antagonists cocktail (D,L-APV, $100 \mu \mathrm{M}$; CNQX, 20 $\mu \mathrm{M}$; MK-801, $20 \mu \mathrm{M})$. Stimulus intensity at $1.5 \mathrm{~mA}$. Bottom trace, IBC (picrotoxin, $50 \mu \mathrm{M} ; \mathrm{D}, \mathrm{L}-\mathrm{APV}, 100 \mu \mathrm{M}$; CNQX, $20 \mu \mathrm{M}$; MK-801, $20 \mu \mathrm{M}$; GYKI-52466, $50 \mu \mathrm{M})$. Stimulus intensity at $2 \mathrm{~mA}$. Whole-cell configuration, Cs-gluconate intracellular solution. $B$, Current-voltage relationship of the peak EPSCs from CA3 cells. Wholecell configuration. Patch electrodes contained $\mathrm{Cs}^{+}$-gluconate and $10 \mathrm{~mm}$ QX-314. Extracellular saline contained IBC plus $10 \mu \mathrm{M}$ nimodipine. Single shock $(100 \mu \mathrm{sec})$ stimulation to CA3 stratum radiatum. The $I-V$ curve fitted a linear regression $(Y=0.96+0.47 X$, and $R^{2}=0.97$ ).

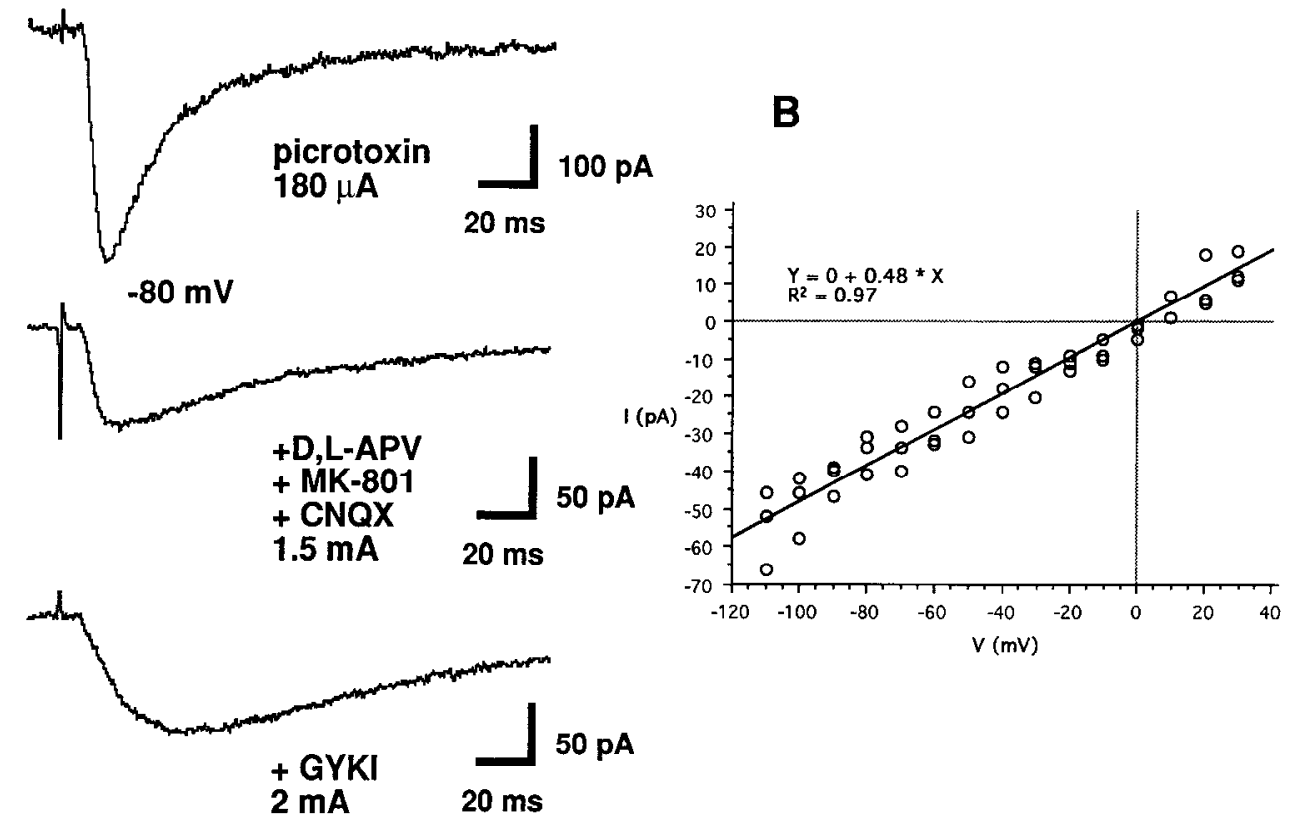

differences were assessed using the Student's $t$ test. $P<0.05$ was considered as significant.

\section{Results}

Fast EPSCs in the presence of competitive and noncompetitive ionotropic glutamate receptor antagonists

Postsynaptic responses in CA3 pyramidal neurons are illustrated in Figure 1A. Stimulation was delivered as single shocks (100 $\mu \mathrm{sec})$ via a bipolar electrode in either the stratum granulosum of the dentate gyrus, the apical dendritic region of $\mathrm{CA} 3$, or the dentate hilus of slice cultures 5-10 d in vitro. Stimulus intensity was adjusted to produce single EPSPs in the range of $10-20 \mathrm{mV}$ (EPSCs in the order of 50-200 pA) for a given electrode placement in control extracellular saline. This level of stimulus amplitude will be defined as low intensity. Figure $1 \Lambda$ (upper trace) illustrates an EPSC evoked by single shock stimulation to to stratum granulosum at low intensity $(180 \mu \mathrm{A})$. Similar postsynaptic responses were observed after stimulation in the hilus (not shown) or stratum oriens of CA3 (toward the CA1 region). The $\mathrm{GABA}_{A}$ antagonist picrotoxin $(50 \mu \mathrm{M})$ was always included in the bathing solution to block inhibitory postsynaptic responses. Bath application of a cocktail containing the ionotropic glutamate receptor competitive antagonists D,L-APV (100 $\mu \mathrm{M}$; Stone

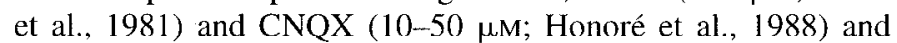
the noncompetitive antagonists MK-801 (20 $\mu \mathrm{M}$; Wong et al., 1986) and GYKI-52466 (50 $\mu \mathrm{m}$; Donevan and Rogawsky, 1993; Zorumsky et al., 1993) blocked the postsynaptic responses evoked by single shock stimulation at low intensity. This cocktail is hereafter called IBC. Similar results were observed with stimulation of the other pathways. The nonselective, competitive ionotropic glutamate receptor antagonist kynurenic acid (1-3 mM; Ganong et al., 1983) was also an effective blocker of these responses.

Figure $1 A$ (middle trace) shows that increasing the single stimulus intensity to $1.5 \mathrm{~mA}$, revealed a postsynaptic response in the presence of APV, CNQX, and MK-801. Slower rise and decay times are evident after increasing the stimulus intensity in this cocktail. In the absence of the GYKI compound the evoked current was 50-60\% larger for a constant stimulus $(59 \pm 8 \mathrm{pA}$ vs $24 \pm 3 \mathrm{pA}, t$ test $p=0.0053, n=6$ ), and had a faster rise time, suggesting that CNQX by itself could not completely block AMPA channels at the large stimulus intensities. This is shown in the comparison of Figure $1 A$, bottom trace, where stimulus intensity was increased to $2 \mathrm{~mA}$ to evoke an EPSC of comparable amplitude. Because of the insolubility of the GYKI compound the full IBC cocktail contained high levels of DMSO $(0.5-0.6 \%)$ and we sometimes omitted it in experiments testing the effects of other extracellularly applied antagonists. The presence or absence of MK801 in the blocking cocktail made almost no difference in the current waveform either for single shocks or tetani. Where brief tetani were given it was not necessary to increase stimulus intensity as much as for single shocks in order to generate responses in the IBC.

Other competitive ionotropic glutamatergic antagonists, such as the AMPA/kainate receptor-selective compound 2-amino-3-[3(carboxymethoxy)-5-methylisoxazol-4-yl]propionic acid (AMOA; $500 \mu \mathrm{M}, n=4$; Krogsgaard-Larsen et al., 1991), and the kainate receptor-selective compound 5-nitro-6,7,8,9-tetrahydrobenzo[g ]indole-2,3-dione-3-oxime (NS-102; $10 \mu \mathrm{M}, n=4$; Johansen et al., 1993; Lerma et al., 1993) gave no further reduction in the postsynaptic responses elicited in IBC. Nicotinic (tubocurarine, $100 \mu \mathrm{M}, n=4$ ) and muscarinic (atropine, $10 \mu \mathrm{M}, n=4$ ) antagonists also did not affect these responses. We shall refer to the postsynaptic currents evoked in IBC-containing competitive and noncompctitive antagonists, as $I_{\mathrm{pm}}$ (postsynaptic metabotropic current) for brevity in the following discussion.

$I_{\mathrm{pm}}$ evoked by single shocks in IBC had a $10-90 \%$ rise time of 15-30 msec. This is much faster than the previously described slow EPSCs mediated through $\mathrm{K}^{+}$channel blockade by mGluR activation (Charpak and Gähwiler, 1991) which showed a rise time of around 4-5 sec (U. Gerber, personal communication). This slow $\mathrm{K}$-conductance responses was also expressed by neurons in our cultures but was blocked by $\mathrm{Cs}^{+}$in the recording 
clcctrods or was minimized by holding membrane voltage near the $\mathrm{K}^{+}$reversal potential when $\mathrm{K}^{+}$recording electrods were used. The rise time of $I_{\mathrm{pm}}$ is considerably slower than the AMPA/ kainate-mediated EPSC that has a $10-90 \%$ rise time of $0.5-2$ msec (Fig. 1A, upper trace), and slower than the NMDA-mediated EPSC, with a rise time of 4-9 $\mathrm{msec}$ in this preparation and elsewhere (Ascher and Nowak, 1988; Ascher et al., 1988; Hestrin et al., 1990a,b; Keller et al., 1991; Williams and Johnston, 1991; Jonas et al., 1993).

$I_{\mathrm{pm}}$ was observed with different recording conditions such as patch electrodes containing $\mathrm{K}^{+}$-gluconate $(n=34)$ or $\mathrm{Cs}^{+}$-gluconate $(n=14)$ in the whole-cell configuration, and with sharp microelectrodes containing $\mathrm{KCl}$ or $\mathrm{K}^{+}$-acetate $(n=4)$. It was also unaffected by intracellular $\mathrm{Ca}^{2+}$ buffering. In $\mathrm{CA} 3$ cells dialyzed with the $\mathrm{Ca}^{2+}$ chelator BAPTA $\left(20 \mathrm{~mm}\right.$ in $\mathrm{K}^{+}$-gluconate, GTP internal solution) the postsynaptic responses evoked in IBC were not significantly affected $(41 \pm 2 \mathrm{pA}$ after $10 \mathrm{~min}$ of whole-cell access vs $39 \pm 2 \mathrm{pA}$ after 60 min, $t$ test $p=$ $0.6559, n=4)$. Diffusion of BAPTA into the cells from the barrel of the patch electrodes was assessed by monitoring the fluorescence of mag-fura $2(500 \mu \mathrm{M})$ included in the solution (see Materials and Methods).

Current-voltage relationships $(I-V)$ were obtained for EPSCs evoked by single shocks in IBC. Patch electrodes containing $\mathrm{Cs}^{+}$-gluconate and QX-314 (2-10 mM), and bath application of the $\mathrm{Ca}^{2+}$ channel blocker nimodipine $(10 \mu \mathrm{M})$ were used to facilitate voltage clamp during steady-state depolarization. The $I-$ $V$ curve fitted a linear regression $\left(R^{2}=0.97\right)$ between $-110 \mathrm{mV}$ and $+30 \mathrm{mV}$, showing a reversal potential of $0 \mathrm{mV}(n=3$; Fig. $1 B$ ). Similar $I-V$ relationships were obtained when stimulation was delivered to stratum oriens $(n=4)$. These observations, together with experiments performed in cells dialysed with $\mathrm{K}^{+}$gluconate showing inward EPSCs at a holding potential of -80 $\mathrm{mV}$ (see Figs. 3-5), exclude the possibility that the EPSCs evoked in IBC represent $\mathrm{K}^{+}$-selective conductances (reversal potential for $\mathrm{K}^{+}=-94 \mathrm{mV}$ with $\left[\mathrm{K}^{+}\right]_{o}=3.24 \mathrm{mM},\left[\mathrm{K}^{+}\right]_{i}=137.5$ $\mathrm{mm}$ ). Instead, they suggest the activation of nonselective cationic channels. Furthermore, membrane input resistance measured with hyperpolarizing voltage pulses $(40 \mathrm{msec}, 20 \mathrm{mV})$ at the pcak of the EPSCs is reduced by 26-37\% (165-177 M $\Omega$ at the peak of the EPSCs vs 240-263.M $\Omega$ two cells), indicating an increase in membrane conductance. Dependence on orthodromic synaptic transmission was confirmed by the blockade of the EPSCs elicited in IBC by bath application of tetrodotoxin (2 $\mu \mathrm{M}, n=4)$.

In the slice culture it proved to be impossible for us to compare the EPSCs in control saline and in the $\mathrm{IBC}$ at the same stimulus strength. In control saline the range over which stimulus strength could be increased and still evoke a reasonably uncontaminated EPSC was very narrow. That is, neurons in the slice cultures are massively interconnected (Zimmer and Gähwiler, 1984, 1987; McBain et al., 1989; Kauer and Tsien, 1990; Mooney et al., 1993; Muller et al., 1993; Sakaguchi et al., 1994) and increasing stimulus strength more than $1.5 \times$ threshold triggered extended dendritic firing even though the soma was held at $-100 \mathrm{mV}$. Within this range of stimulus (low intensity), any responses in the IBC were generally within the noise. We were however able to obtain a response comparison to a common stimulus amplitude in CA 3 neurons of acute slice where the range of useable stimulus proved to be wider. Figure $2 A$ shows EPSCs of a CA3 neuron in acute slice preparation in control saline (upper trace) and in the IBC (middle and lower traces).
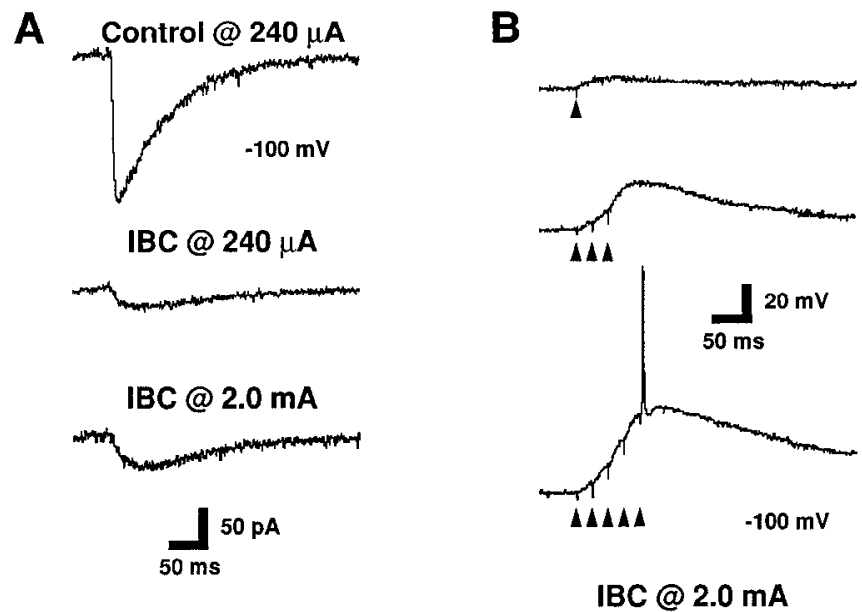

Figure 2. A: Upper trace, Normal EPSCs in CA3 neuron of acute hippocampal slice. Middle trace, $I_{\mathrm{pm}}$ evoked by stimulus pulse of same amplitude. Lower trace, $I_{\mathrm{pm}}$ evoked by more intense stimulus. Soma voltage was held at $-100 \mathrm{mV}$ under single microelectrode voltage clamp. Seventy milliseconds before the stimulus shock, soma voltage was stepped an additional $-10 \mathrm{mV}$. Current relaxation gives the slight upward drift of the baseline in the records. Traces are averages of 10 responses. $B$, EPSPs generated by high-intensity stimulus in the IBC. Holding voltage was $-100 \mathrm{mV}$ to emphasize nonlinear summation during a brief tetanus.

The cell soma was held at $-100 \mathrm{mV}$ and given an additional $10 \mathrm{mV}$ hyperpolarizing pulse $70 \mathrm{msec}$ before the stimulus shock. This enabled the shock amplitude to be increased to two or three times the low-intensity range (see above) without firing the dendrites. In the upper and middle traces, single stimulus shocks $(100 \mu \mathrm{sec})$ of the same amplitude $(240 \mu \mathrm{A}$, about three times low intensity) were delivered to stratum lucidum. The IBC reduced the EPSC under these conditions by approximately $85 \%$. Lower amplitude stimulus pulses $(<150 \mu \mathrm{A})$ failed to generate a measureable EPSC in the IBC, as was the case in the slice cultures. In the lower trace the stimulus amplitude was increased eightfold, generating a larger EPSC and showing that the rise time of the current in the IBC was considerably slower than the control EPSC as was the case in the slice cultures. Figure $2 B$ shows that the EPSPs summate in a nonlinear fashion and can drive the cell to spike threshold. Additional experiments $(n=$ 3) have also confirmed the presence of a response similar to $I_{\mathrm{pm}}$ in CA3 neurons of standard acute slices from adult rat. With the soma held at $-70 \mathrm{mV}$, inward currents of $0.2-3.0 \mathrm{nA}$ were elicited by high-intensity tetanic stimuli $(0.1-1.0 \mathrm{sec}, 50 \mathrm{~Hz})$ in the presence of the IBC. At $+20 \mathrm{mV}$, outward currents were elicited by the tetani. Therefore, the phenomenon we are defining is also expressed in normally differentiated neurons.

Involvement of $P T X$-insensitive $G$ protein-coupled receptors in the fast EPSC's evoked in ionotropic glutamate receptor antagonists

To test directly the involvement of $\mathrm{G}$ protein-coupled receptors in the activation of $I_{\mathrm{pm}}$, we employed a patch electrode perfusion system (Tang et al., 1990) in the slice culture. Intracellular perfusion up to $1 \mathrm{hr}$ with $\mathrm{K}^{+}$-gluconate-based solutions containing GTP $(200 \mu \mathrm{M})$ did not affect the holding current or the EPSCs evoked in a cocktail including only competitive antagonists (59 $\pm 11 \mathrm{pA}$ after $5 \mathrm{~min}$ of perfusion vs $68 \pm 11 \mathrm{pA}$ after $45 \mathrm{~min}$ of perfusion, $t$ test $p=0.2930, n=3$; Fig. 3, top and middle traces). The time plot shows the stability of the holding current 
Figure 3. Stability of EPSCs and holding current during GTP perfusion. Left, Peak EPSC amplitude (open circles) and holding current (solid circles, ) versus time of whole-cell patch perfusion. Right: Top trace, EPSC after $10 \mathrm{~min}$ of perfusion (arrow in time plot). Middle trace, EPSC after $30 \mathrm{~min}$ of perfusion. Holding potential -80 mV. Bottom trace, Postsynaptic current induced by bath applied $10 \mu \mathrm{M}$ baclofen (bar) after 40 min of perfusion with intracellular solution containing 200 $\mu \mathrm{M}$ GTP. Holding potential $-45 \mathrm{mV}$. EPSCs evoked by single shock (100 $\mu \mathrm{sec})$ to dentate gyrus stratum granulosum. Patch electrodes contained $\mathrm{K}^{+}$gluconate and GTP when whole-cell access was established. Extracellular saline contained $50 \mu \mathrm{M}$ picrotoxin, 100 $\mu \mathrm{M}$ D,L-APV, $50 \mu \mathrm{M}$ CNQX.

\section{EPSC's in APV-CNQX during whole-cell perfusion with GTP}

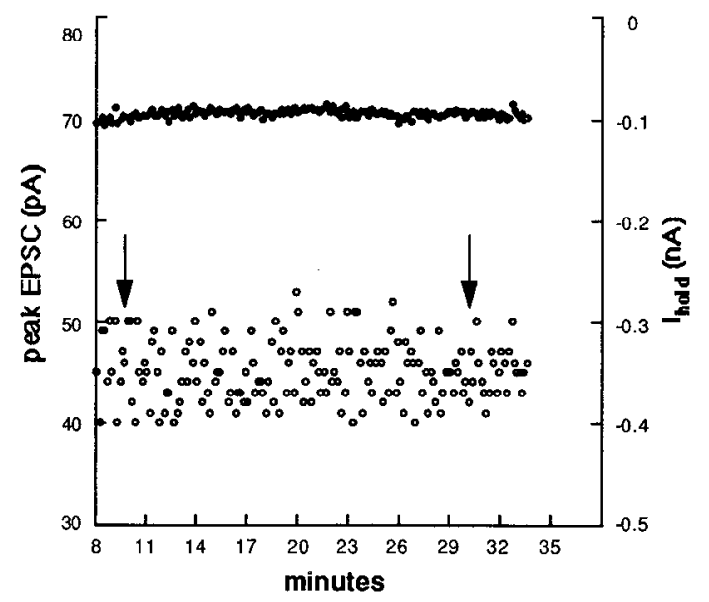

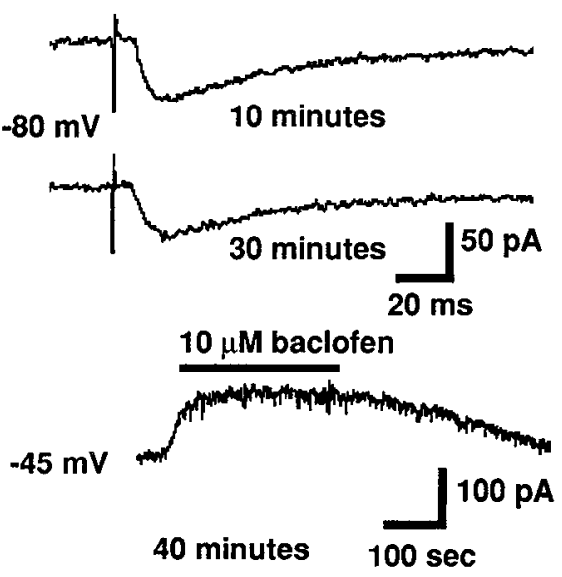

(right y-axis) and of the peak EPSC amplitude (left y-axis) during intracellular perfusion of GTP. Baclofen $(10 \mu \mathrm{M})$ elicited an outward current $(67 \pm 19 \mathrm{pA}, n=3$; Fig. 3 , bottom trace) known to be mediated by the $G$ protein-dependent opening of $\mathrm{K}^{+}$channels (Gähwiler and Brown, 1985; Dutar and Nicoll, 1988; Thalmann, 1988).

Guanosine-5'-O-2-thiodiphosphate (GDP $\beta S$ ), a nonhydrolyzable analog of GDP, competes with GTP for the binding site at the $\alpha$ subunit, and when present at higher concentrations than cellular GTP (around $25 \mu \mathrm{M}$; Breitwieser and Szabo, 1988), locks the GTPase cycle in an inactivated status (Gilman, 1987; Ross, 1989; Hepler and Gilman, 1992). It also depletes the cellular GTP supply by inhibiting its synthesis from GDP (Breitwieser and Szabo, 1988). Intracellular perfusion with $\mathrm{K}^{+}$-gluconate-based solutions containing GDPBS $(500 \mu \mathrm{M}$, in the absence of GTP) had no effect in the holding current, while EPSCs evoked in the IBC were almost completely blocked (46 \pm 12 pA before perfusion vs $5 \pm 2 \mathrm{pA}$ after $30 \mathrm{~min}, t$ test $p=0.0084$, $n=4$; Fig. 4 top and middle traces). The response to baclofen was also absent after GDP $\beta S$ perfusion ( $n=4$; Fig 4 , bottom trace), confirming the blockade of $G$ protein-coupled responses. The time plot shows the stability of the holding current (right $y$-axis) and the reduction of the peak EPSC amplitude (left y-axis) during intracellular perfusion of GDPBS.

GDPßS perfusion had no effect on the AMPA/kainate component of the synaptic current. EPSCs cvoked in the presence of only D,L-APV $(100 \mu \mathrm{M})$ and picrotoxin $(50 \mu \mathrm{M})$, using lower stimulus intensities averaged $168 \pm 12 \mathrm{pA}$ peak amplitude after 5 min perfusion vs $193 \pm 14 \mathrm{pA}$ after $30 \mathrm{~min}$ ( $t$ test $p=0.1345$, $n=3)$ while the response to baclofen was abolished $(n=3)$. In a blocking cocktail without GYKI-52466 (i.e., CNQX, MK801, APV), GDP $\beta$ S perfusion blocked approximately $60 \%$ of the EPSC $(115 \pm 13 \mathrm{pA}$ vs $51 \pm 11 \mathrm{pA}, n=6$; see also Fig. 7). This fractional block is quantitatively what would be expected with a small residual AMPA channel component of the EPSC (as in Fig. 1 $A$, middle trace) that is unaffected by GDP $\beta S$.

Pertussis toxin (PTX) uncouples $G_{i}$ and $G_{0}$ subtypes of $G$ proteins from receptors by ADPribosylation of the cysteine res-

\section{EPSC's in IBC during whole-cell perfusion with GDP $\beta S$}

Figure 4. Effect of GDPßS perfusion on EPSCs and holding current. Left, Peak EPSC amplitude (open circles) and holding current (solid circles) as a function of perfusion time. Right: Top trace, EPSC after $10 \mathrm{~min}$ of perfusion with intracellular solution containing $500 \mu \mathrm{M}$ GDPßS (arrow in time plot). Middle trace, EPSC after $35 \mathrm{~min}$ perfusion Holding potential $-80 \mathrm{mV}$. Bottom trace, Postsynaptic current induced by bath-applied $10 \mu \mathrm{M}$ baclofen (bar) after $40 \mathrm{~min}$ of perfusion. Holding potential $-45 \mathrm{mV}$. EPSCs evoked by single shocks $(100 \mu \mathrm{sec})$ to dentate gyrus stratum granulosum. Patch electrodes contained $\mathrm{K}^{+}$-gluconate and GTP when whole-cell access was established. Extracellular saline contained IBC (picrotoxin, $50 \mu \mathrm{M} ; \mathrm{D}, \mathrm{L}-\mathrm{APV}, 100 \mu \mathrm{M}$; CNQX, $20 \mu \mathrm{M}$; MK-801, $20 \mu \mathrm{M}$; GYKI-52466, $50 \mu \mathrm{M})$.
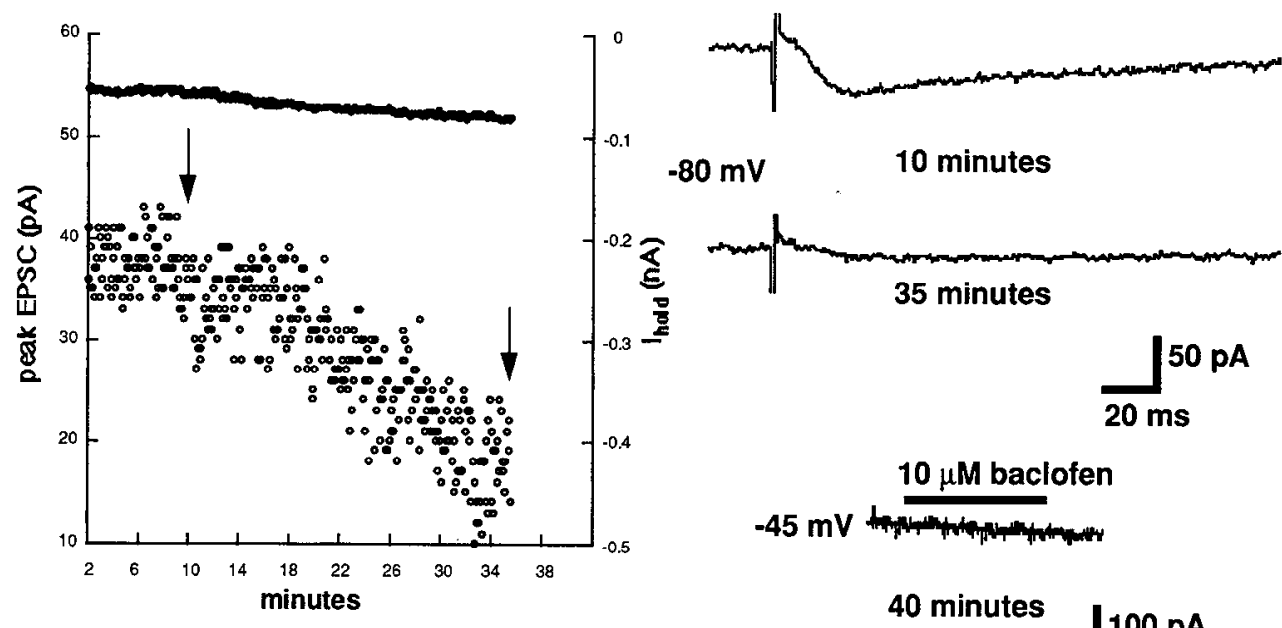

$-80 \mathrm{mV} \quad 10$ minutes

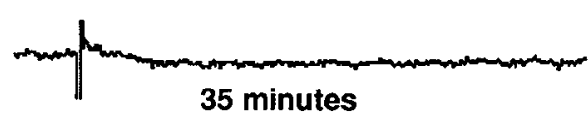

35 minutes
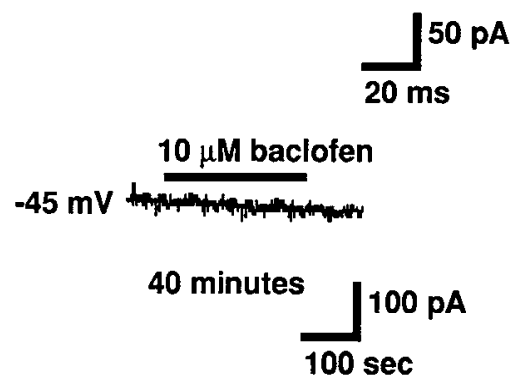

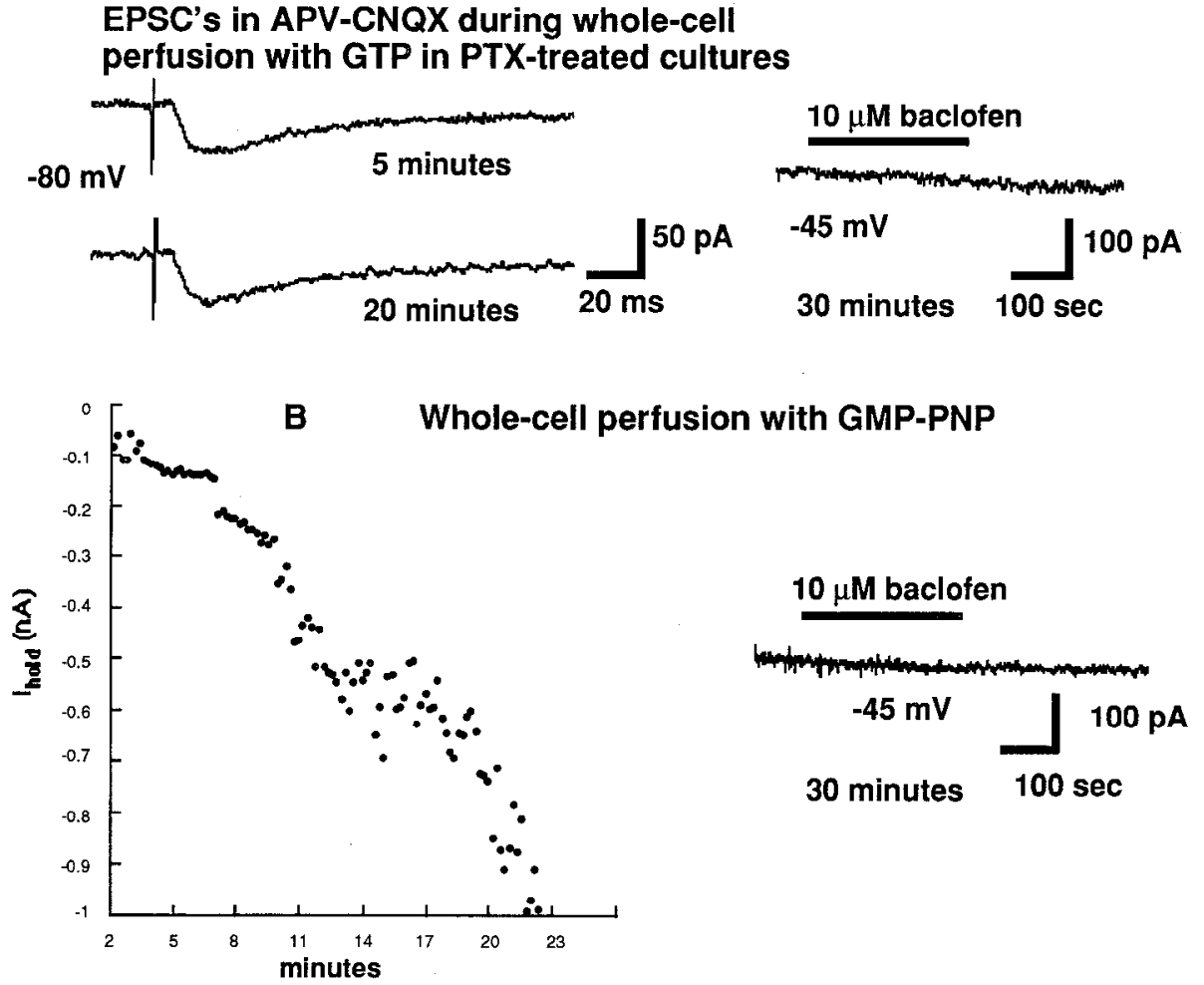

idue in the $\alpha$ subunit (Gilman, 1987; Ross, 1989; Hepler and Gilman, 1992). A set of experiments was done on hippocampal slice cultures incubated in media containing PTX $(500 \mathrm{ng} / \mathrm{ml})$ for 48-72 hr. EPSCs evoked in a cocktail including only competitive antagonists were not affected in neurons perfused with $\mathrm{K}^{+}$-gluconate-based intracellular solutions containing GTP (200 $\mu \mathrm{M})$ from PTX-treated cultures $(64 \pm 7 \mathrm{pA}$ control vs $64 \pm 5$

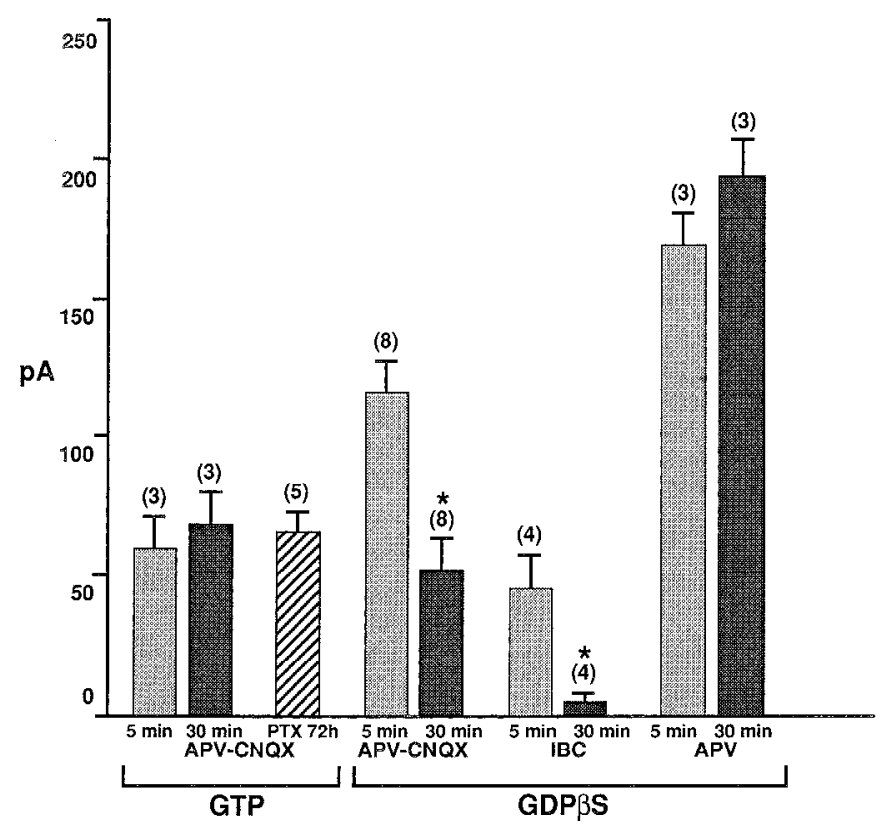

Figure 6. Summary of peak EPSC amplitudes evoked in the presence of ionotropic glutamate receptor antagonists during whole-cell intracellular perfusion. Bars represent means \pm SEM. Numbers in parenthesis indicate the number of cells. Asterisks indicate significant statistical differences by Student's $t$ test $(p<0.05)$.
pA PTX cultures, $t$ test $p=0.4727, n=5$; rig. $5 A$ ). 'lo test the effectiveness of the incubation on a known PTX-sensitive $G$ protein-coupled receptor, the $\mathrm{GABA}_{\mathrm{B}}$ receptor agonist baclofen was applied to the extracellular saline. PTX incubation abolished outward currents evoked by baclofen ( $n=5$; Fig. $5 A$, right trace).

Guanylyl-imidodiphosphate (GMP-PNP), a nonhydrolyzable analog of GTP, binds to $\alpha$ subunits but cannot be hydrolyzed to GDP, activating $G$ proteins irreversibly, and causing persisting activation of effector proteins (Gilman, 1987; Ross, 1989; Hepler and Gilman, 1992). Intracellular perfusion with $\mathrm{K}^{+}$-gluconate-based solutions containing GMP-PNP $(250 \mu \mathrm{M}$, in the absence of GTP) induced a slowly increasing inward current (520 \pm 58 pA, $n=5$; Fig. $5 B$ ) and increased membrane conductance. The importance of this finding is that it shows the activated $G$ protein subunits can produce an inward current of adequate size to account for the amplitude of $I_{\mathrm{pm}}$ in these neurons. $I_{\mathrm{pm}}$ was also occluded by this perfusion $(54 \pm 9$ pA vs $20 \pm 4$ pA after 15 $\min t$ test $p=0.0031, n=6$ ), but AMPA currents were reduced as well $(120 \pm 21 \mathrm{pA}$ vs $68 \pm 15 \mathrm{pA}$ after $35 \min t$ test $p=$ $0.0342, n=6$ ), unlike the case for GDPBS perfusion. The reduction of AMPA currents was probably the result of decreased electrotonic length resulting from the conductance increase, therefore the data of Figure $5 B$ alone cannot be used to argue that the occlusion of $I_{\mathrm{pm}}$ is solely a $\mathrm{G}$ protein effect. The response to baclofen was absent in cells intracellularly perfused with GMP-PNP ( $n=4$; Fig. $5 B$, right trace). Figure 6 summarizes EPSC amplitudes during whole-cell intracellular perfusion in different antagonist mixtures.

Involvement of metabotropic glutamate receptors in the fast EPSCs evoked in ionotropic glutamate receptor antagonists

This series of experiments was carried out using only the competitive ionotropic inhibitors CNQX and APV in order to reduce 
Figure 7. A, Reversible block of $I_{\mathrm{pm}}$ by putative mGluR antagonists (stimulus to stratum radiatum). Left traces, MCPG; right traces, L-AP3. Extracellular saline contained $50 \mu \mathrm{M}$ picrotoxin, $100 \mu \mathrm{M}$ D,L-APV, $50 \mu \mathrm{M}$ CNQX Holding potential $-80 \mathrm{mV} . B, \mathrm{~L}-\mathrm{AP} 3$ is ineffective in blocking $I_{\mathrm{pm}}$ elicited by stimulation of stratum oriens, while MCPG still blocks the current. Extracellular saline contained $50 \mu \mathrm{M}$ picrotoxin, $100 \mu \mathrm{M}$ D,L-APV, $50 \mu \mathrm{M}$ CNQX, $10 \mu \mathrm{M}$ atropine. $C$, Demonstration, using the same neuron, that L-AP3 is effective against stratum radiatum stimulus but not against stratum oriens stimulation. Paired stimulus records are continuous, with arrows marking the stimuli. Extracellular saline contained $50 \mu \mathrm{M}$ picrotoxin, $100 \mu \mathrm{M}$ D,L-APV, 50 $\mu \mathrm{M}$ CNQX. Patch electrode contained $\mathrm{Cs}^{+}$-gluconate throughout and $2 \mathrm{~mm}$ QX-314 in $C$.
A stratum radiatum

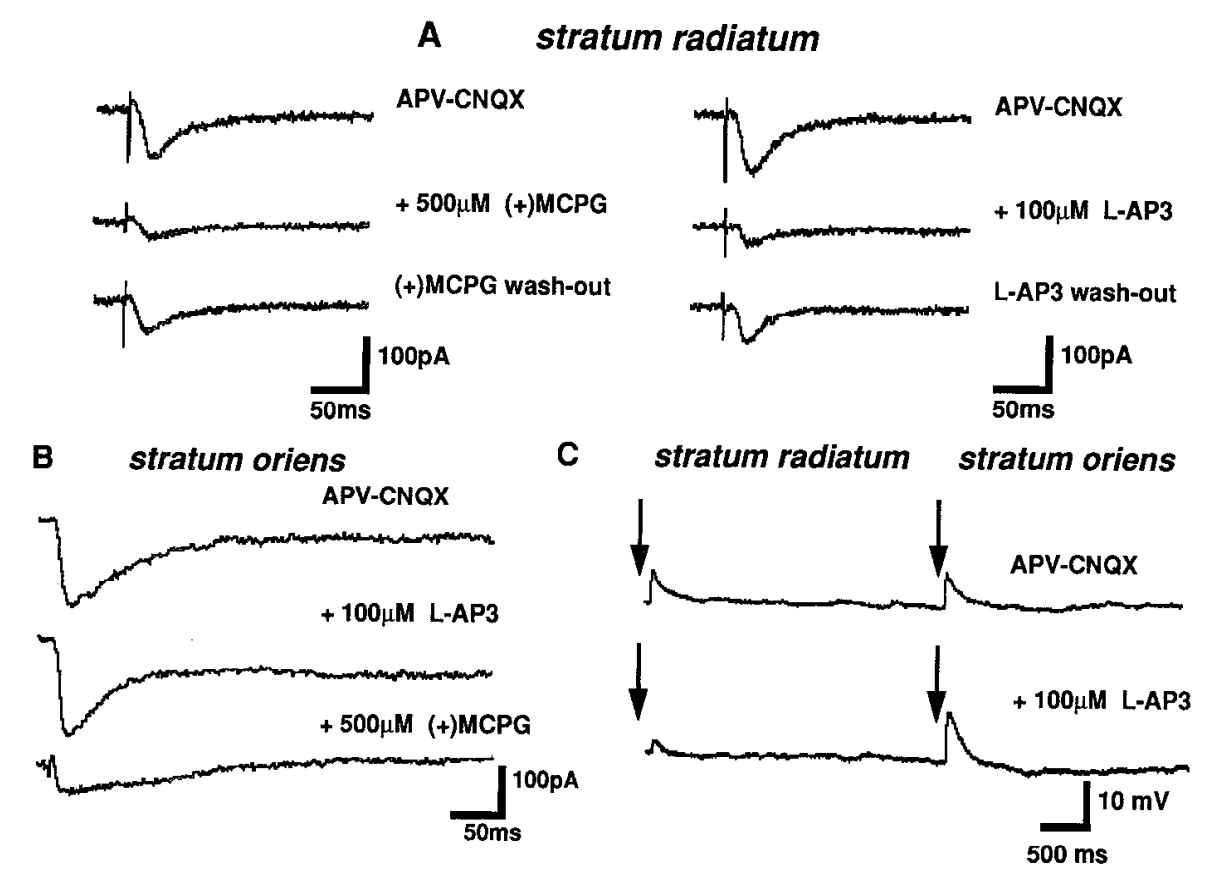

the possibility of drug interactions and to minimize DMSO concentration during long experiments. Bath application of the putative mGluR antagonist $(R, S)$ - $\alpha$-methyl-4-carboxyphenylglycine $[(R, S) \mathrm{MCPG} ; 0.5-1 \mathrm{~mm}$; or its active isomer $(+) \mathrm{MCPG}$, 250-500 $\mu \mathrm{M}$; Eaton et al., 1993] reversibly reduced the EPSCs evoked by single shocks in CA3 stratum radiatum (or DG stratum granulosum; $143 \pm 23 \mathrm{pA}$ vs $52 \pm 9 \mathrm{pA}, t$ test $p=0.0016$, $n=7$ ). After $20-30 \mathrm{~min}$ of washout a recovery was observed $[130 \pm 15 \mathrm{pA}$ vs $43 \pm 3 \mathrm{pA}$ vs $74 \pm 9 \mathrm{pA}$, control vs (+)MCPG vs washout, $n=5$; Fig. $7 A$, left traces].

Application of another putative mGluR antagonist, $\mathrm{L}(+)-2-$ amino-3-phosphonopropionic acid (L-AP3; $100 \mu \mathrm{M}$; Schoepp and Johnson, 1989) also reversibly reduced the EPSCs evoked
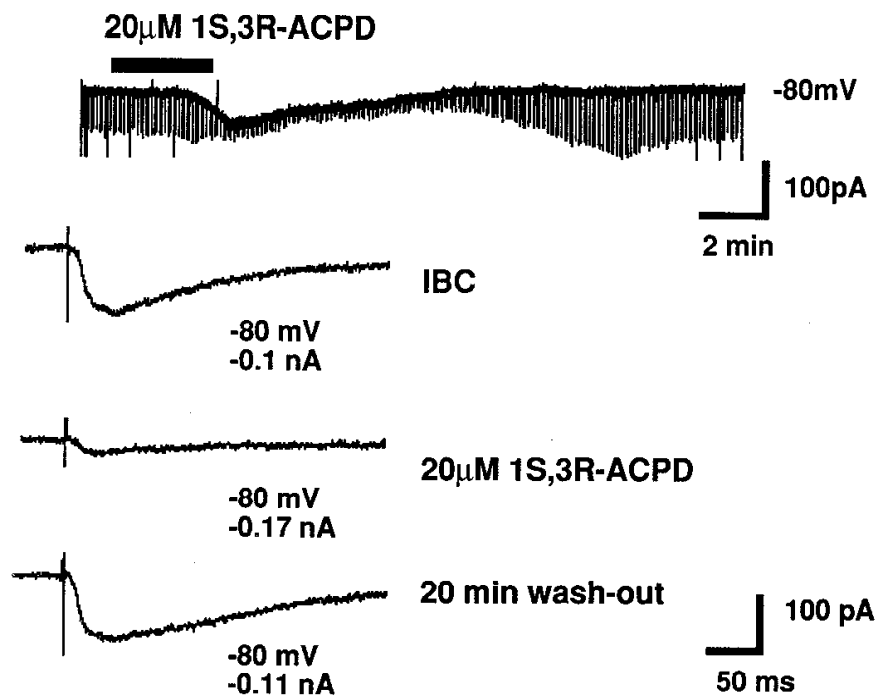

Figure 8. Top trace, 1S,3R-ACPD (bar) activates an inward current in a CA3 neuron voltage-clamped at $-80 \mathrm{mV}$. Downward deflections represent EPSCs evoked by single shocks at high stimulus intensity. Lower traces, EPSCs extracted from before (upper), during steady state (middle), and after recovery of the inward current activated by $1 S, 3 R$ ACPD (bottom). by $50 \mathrm{~Hz}, 500 \mathrm{msec}$ trains in CA3 stratum radiatum (or DG stratum granulosum; $168 \pm 52 \mathrm{pA}$ vs $72 \pm 16 \mathrm{pA}, t$ test $p=$ $0.05 ; n=7)$, or single shocks $(156 \pm 29 \mathrm{pA}$ vs $86 \pm 23 \mathrm{pA}, t$ test $p=0.046, n=7)$. Upon washout of L-AP3 (20-30 min) a recovery was observed $(110 \pm 34 \mathrm{pA}$ vs $45 \pm 16 \mathrm{pA}$ vs $96 \pm$ 27 pA, control vs L-AP3 vs washout, $n=3$; Fig. $7 A$, right traces). Further application of $(R, S) \mathrm{MCPG}$ in the presence of L-AP3 produced an additional 50\% reduction of the EPSCs ( $n$ $=2$ ).

Surprisingly, L-AP3 $(100 \mu \mathrm{M})$ had no effect on the EPSCs evoked by single shocks in CA3 stratum oriens (134 \pm 27 pA vs $144 \pm 38 \mathrm{pA}, t$ test $p=0.5805, n=3$; Fig. $7 B$ or $50 \mathrm{~Hz}$, $500 \mathrm{msec}$ trains $(149 \pm 28 \mathrm{pA}$ vs $140 \pm 29 \mathrm{pA}, t$ test $p=$ $0.4141, n=4)$. In contrast, $(R, S) \mathrm{MCPG}(0.5-1$ InM) oI $(+) M C P G(200-400 \mu \mathrm{M})$ significantly reduced the EPSCs evoked hy single shocks in CA3 stratum oriens in (134 \pm 27 pA vs $63 \pm 30 \mathrm{pA}, t$ test $p=0.05, n=3$; Fig. $7 B$ ). These results were confirmed by stimulating DG stratum granulosum and CA3 stratum oriens with two different bipolar electrodes, while recording from the same $\mathrm{CA} 3$ cell. After stable recording of subthreshold responses, bath application of L-AP3 (100 $\mu \mathrm{M})$ only reduced the EPSPs elicited by stimulation through the DG stratum granulosum electrodes $(n=3$; Fig. $7 C)$. Neither L-AP3 nor (+)MCPG noticeably reduced EPSCs elicited by low amplitude stimulus in control saline, suggesting that the effects of the putative mGluR antagonists were mediated at postsynaptic receptors, and/or were not exerted on NMDA or AMPA/kainate receptors $(n=3)$.

Application of the mGluR selective agonist $1 S, 3 R$-ACPD (20$50 \mu \mathrm{M}$; Irving ct al., 1990) induced an inward current in the presence of the full IBC at a holding potential of $-80 \mathrm{mV}(64$ \pm 4 pA, $n=3$; Fig. 8), and reversibly occluded the FPSCs (138 $\pm 27 \mathrm{pA}$ vs $25 \pm 10 \mathrm{pA}, t$ test $p=0.0167, n=3$; Fig. 8). Figure 8 shows that after $10-15 \mathrm{~min}$ of washout a full recovery of the EPSCs was observed $(71 \pm 2 \mathrm{pA}, n=3)$. The possibility of a depression of the EPSCs by a presynaptic effect of $1 S, 3 R$ ACPD (Baskys and Malenka, 1991) must be recognized as a contributing factor. The isomer $1 S, 3 S$-ACPD mimicks the post- 
synaptic effects of $1 S, 3 R$-ACPD without depressing the evoked field EPSP (Desai et al., 1992). This agonist $(50 \mu \mathrm{M})$ induced an inward current at $-80 \mathrm{mV}(53 \pm 17 \mathrm{p} \Lambda, n-3)$, and also reduced the evoked EPSCs $(84 \pm 8 \mathrm{pA}$ vs $22 \pm 4 \mathrm{pA}, t$ test $p$ $=0.0029, n=3$ ). However, no recovery of the holding current and EPSCs were observed after washout of $1 S, 3 S$-ACPD. This isomer produced a high level of maintained excitation that perhaps caused cell deterioration.

Current-voltage relationships of the $1 S, 3 R$-ACPD induced currents were constructed from voltage ramp protocols from -80 to $+10 \mathrm{mV}(4 \mathrm{sec})$ before and after the application of the agonist. Substracted $I-V$ relationships $(n=3)$ were averaged and fit by linear regression. The extrapolated reversal potential was $+9.2 \mathrm{mV}$, close to the reversal potential of the evoked EPSCs $(0 \mathrm{mV})$, and of monovalent cations as predicted by the Nernst equation $(-2 \mathrm{mV})$ at the experimental conditions of [cat-

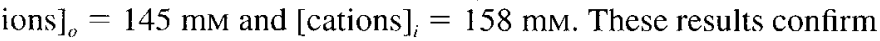
a recent study of currents induced by mGluR agonists in CA3 neurons of organotypic cultures (Guérineau et al., 1995). A response to $\mathrm{mGluR}$ agonists in $\mathrm{CA} 1$ neurons also reverses around $0 \mathrm{mV}$ but has different characteristics in that it appears to require and increase in intracellular $\mathrm{Ca}^{2+}$ (Crépel et al., 1994).

\section{Discussion}

The present data describe a fast excitatory postsynaptic response elicited in CA3 neurons in the presence of compctitive and noncompetitive antagonists of ionotropic glutamate receptors. The response, termed here $I_{\mathrm{pm}}$, is present in CA3 neurons of both acute and cultured slice preparations. The activation time course of the EPSC (10-90\% rise time of $15-30 \mathrm{msec}$ at $23-24^{\circ} \mathrm{C}$ ) is much faster than a slow EPSC mediated through $\mathrm{K}^{+}$channel blockade by mGluR activation, but slower than the AMPA/kainate current $(0.5-2 \mathrm{msec})$. The time course of $I_{\mathrm{pm}}$ is closer to that of the NMDA current (4-9 msec rise time) but has a linear $I-V$ relationship, and negligible $\mathrm{Ca}^{2+}$ permeability (Connor et al., 1994; Pozzo Miller, Petrozzino, and Connor, unpublished observations). The linear $I-V$ relationship and lack of significant $\mathrm{Ca}^{2+}$ permeability together with the reversal potential around $0 \mathrm{mV}$, suggest the opening of nonselective, monovalent cationic channels. Activation of $I_{\mathrm{pm}}$ does not require and intracellular $\mathrm{Ca}^{+}$ increase.

The involvement of metabotropic glutamate receptors, as opposed to residual activation of ionotropic glutamate receptors, in the activation of $I_{\mathrm{pm}}$ is inferred from the following: (1) $I_{\mathrm{pm}}$ could be elicited by high-amplitude stimulation in a full complement of competitive and noncompetitive ionotropic glutamate receptor antagonists and $\mathrm{Mg}^{2+}$, as well as antagonists of other receptor types. In acute slices, it constituted up to $15 \%$ of the total current at a given stimulus intensity. (2) Intracellular perfusion of GBP $\beta S$ blocked $I_{\mathrm{pm}}$, but had no effect on pharmacologically isolated AMPA/kainate currents. (3) The putative mGluR antagonists L-AP3 and $(R, S) \mathrm{MCPG}$ [or $(+) \mathrm{MCPG}]$ sharply reduced the evoked EPSCs in APV and CNQX, but not in control saline and low amplitude stimulus. (4) The selective mGluR agonist $1 S, 3 S$-ACPD activated an inward current with similar reversal potential and occluded $I_{\mathrm{pm}}$.

Synaptic responses insensitive to ionotropic glutamate receptor competitive antagonists have been described in acute neocortical slices from adult rat after $\mathrm{GABA}_{\mathrm{A}}$ receptor blockade (Zhou and Hablitz, 1993), and in kindled rat basolateral amygdala (Rainnie et al., 1992). Whether these responses are linked to $\mathrm{G}$ proteins or activated by mGluRs has not been reported.
However, a fast EPSP (time to peak of $10-20 \mathrm{msec}$ ) sensitive to $(+) \mathrm{MCPG}$ has been recorded in dorsolateral septal nucleus neurons in the presence of the competitive antagonists $D, L-A P V$ and CNQX (Gallagher et al., 1995).

Incubation of the slice cultures in PTX did not affect $I_{\mathrm{pm}}$, but did block responses mediated by $\mathrm{GABA}_{\mathrm{B}}$ receptors, consistent with previous findings that not all mGluRs are coupled to PTXsensitive G proteins (Gerber et al., 1992; Gallagher and Zheng, 1993; Shirasaki et al., 1994). The participation of pharmacologically different subtypes of mGluRs, possibly reflecting the diversity of cloned mGluR subtypes, was suggested by the differential sensitivity to L.-AP3 and $(R, S)$ MC.PG [or (+)MCPG] observed in the two pathways stimulated (CA3 stratum radiatum vs CA3 stratum oriens).

The parsimonious model for $I_{\mathrm{pm}}$ activation is that one or more subtypes of perisynaptic mGluRs (see below) are coupled to $G$ proteins that can activate the opening of monovalent cationic channels in a membrane-delimited mechanism. A more complex interaction involving both $\mathrm{G}$ protein-coupled receptor modulation and ligand binding to a novel subtype of ionotropic glutamate receptor insensitive to CNQX and GYKI-52466 is also possible.

Activation of $I_{\mathrm{pm}}$ is rapid compared to the modulation of ion channels by other $G$ protein, second messenger-coupled receptors (i.e., Cole and Nicoll, 1984; Charpak and Gähwiler, 1991; for rcvicw, scc Nicoll ct al., 1990; Hille, 1992). However, other examples exist where activation is nearly as rapid, and where it has been proposed that a membrane-delimited coupling occurs, involving receptor, $\mathrm{G}$ protein, and ion channel (Brown, 1991, 1993; but see Clapham, 1994). In atrial muscle cells muscarinic activation induces $\mathrm{K}^{+}$channel opening by a fast $(30-150 \mathrm{msec}$ latency) membrane-delimited mechanism (Breitwieser and Szabo, 1985; Pfaffinge el al., 1985). Application of purified or recombinant activated $\alpha$ subunits (Codina et al., 1987; VanDongen et al., 1988; Mattera et al., 1989) or $\beta \gamma$ complex (Logothetis et al., 1987; Wickman et al., 1994) to inside-out patches of membrane-induced fast opening of $\mathrm{K}^{+}$channels in the absence of ligand and any other cytoplasmic components. The open channel probability of a chloride conductance in inside-out patches from cultured hippocampal cells is increased by GTP $\gamma S$, and diminished by GDP $\beta S$, suggesting a direct modulation of the $\mathrm{Cl}^{-}$channel by $G$ proteins (Mager et al., 1995). $\Lambda$ similar model has been postulated for the $\mathrm{GABA}_{\mathrm{B}}$ (Pfrieger et al., 1994) and mGluR (Lester and Jahr, 1990; Swartz and Bean, 1992; Trombley and Westbrook, 1992; Sahara and Westbrook, 1993) inhibition of presynaptic $\mathrm{Ca}^{2+}$ currents, and for postsynaptic activation of $\mathrm{GABA}_{\mathrm{B}}$ receptors (Thalmann, 1988; Otis et al., 1993) where no dialysable cytoplasmic factors have been identified as second messenger elements in the receptor-G protein cascade. Pharmacologically isolated $\mathrm{GABA}_{\mathrm{B}}$-mediated synaptic currents have a rise time of around $50 \mathrm{msec}$ in hippocampal slices (Otis et al., 1993). Activation of $G$ proteins has been estimated to be 6-8 msec based on kinetic measurements in the transducin/cGMP cascade in rod outer segments (Vuong et al., 1984). The G protein-coupled $\alpha 2$-adrenoceptors also exhibit fast onset kinetics, with a 10-90\% rise time of around $85 \mathrm{msec}$ (Surprenant and North, 1988).

Experimentally, $I_{\mathrm{nm}}$ was recruited in one of two ways, either by increasing single shock amplitude three to ten times over the level used to elicit subthreshold AMPA/kainate and NMDA EPSPs, or by giving a high-frequency train of lower amplitude shocks (see Fig. 1). Increasing the field stimulus amplitude 
should recruit more fibers that synapse onto the neuron (but not more inputs to a given dendritic spine), while the low-amplitude tetanus should simply supply an increased amount of transmitter at the same postsynaptic sites. Both paradigms are probably effective in recruiting $I_{\mathrm{pm}}$ because they should each increase glutamate levels at synaptic contacts, but they would do so by different means. Single shock excitation, regardless of the amplitude, should produce invariant release at a given bouton, but recruitment of more fibers synapsing in the same general vicinity might well increase glutamate levels away from the synaptic contact zone. Similarly, tetanic stimulation might tend to overload local uptake mechanisms for glutamate and allow "spillover" into perisynaptic areas. The fact that both paradigms work would therefore indicate that the relevant receptors are perhaps not in the synaptic zone. The postsynaptic distribution of $\mathrm{m}$ GluRs is different than that of ionotropic glutamate receptors. Staining for mGluR $1 \alpha$ subunit was preferentially localized at the periphery of the postsynaptic densities, as well at extrasynaptic dendritic and somatic membranes (Baude et al., 1993; Nusser et al., 1994). Activation of the fast EPSPs in dorsolateral septal nucleus neurons in ionotropic antagonists also required high stimulus intensities (Ġallagher et al., 1995). High-frequency "supramaximal" stimulation in the presence of D,L-APV and CNQX is also necessary for the synaptic activation of an MCPG-sensitive EPSP at the parallel fiber-Purkinje cell synapse in cerebellar slices (Batchelor et al., 1994). Similarly, higher stimulus amplitude is required for the synaptic activation of PTX-sensitive, G protein-coupled "metabotropic" $\mathrm{GABA}_{\mathrm{B}}$ receptors, compared with the activation of "ionotropic" $\mathrm{GABA}_{A}$ receptors (Mody et al., 1994).

It is possible that differential spread of transmitter with lowand high-amplitude stimuli plays a role in more complex cell behavior. For example in hippocampal slices from mice lacking the tyrosine kinase gene fyn, tetanic stimulation at a stimulus strength that induced LTP in wild-type mice, failed in the mutants, while stimulation at higher stimulus intensities induced LTP in the mutants comparable to that obtained in wild-type mice (Grant et al., 1992). Similar observations of a dependence on stimulus strength to induce wild-type-like LTP were made in hippocampal slices from neuronal nitric oxide synthase knock out mice (O'Dell et al., 1994). It is also probable that $I_{\mathrm{pm}}$ will be activated during the widespread glutamate increase that accompanies ischemic or traumatic brain injury (Rothman and Olney, 1986; Choi, 1988). It would then provide a source of depolarizing membrane current that is not affected by the known ionotropic glutamate receptor antagonists or blockers of voltagegated $\mathrm{Na}^{+}$and $\mathrm{Ca}^{2+}$ channels. In fact, a predictable pattern of pyramidal cell death dependent on glutamatergic synaptic transmission occurs in slice cultures after 2-3 weeks in vitro (Pozzo Miller et al., 1994a; Kasof et al., 1995). As such, $I_{\mathrm{pm}}$ could be one of the contributing factors, along with voltage- or exchangemediated $\mathrm{Ca}^{2+}$ entry, in neuronal cell injury and death.

\section{References}

Abe T, Sugihara H, Nawa H, Shigemoto R, Mizuno N, Nakanishi S (1992) Molecular characterization of a novel metabotropic glutamate receptor mGluR5 coupled to inositol phosphate/ $\mathrm{Ca}^{2+}$ signal transduction. J Biol Chem 267:13361-13368.

Aniksztejn L, Bregestovski P, Ben-Ari Y (1991) Selective activation of quisqualate metabotropic receptor potentiates NMDA but not AMPA responses. Eur J Pharmacol 205:327-328.

Aramori I, Nakanishi S (1992) Signal transduction and pharmacolog- ical characteristics of a metabotropic glutamate receptor, mGluR1, in transfected $\mathrm{CHO}$ cells. Neuron 8:757-765.

Ascher P, Nowak L (1988) Quisqualate- and kainate-activated channels in mouse central neurones in culture. J Physiol (Lond) 399:227-245.

Ascher P, Bregestovsky P, Nowak L (1988) N-methyl-D-aspartate-activated channels of mouse central neurones in magnesium-free solutions. J Physiol (Lond) 399:207-226.

Bashir ZI, Bortolotto ZA, Davies CH, Beretta N, Irving AJ, Seal AJ, Henley JM, Jane DE, Watkins JC, Collingridge GL (1993a) Induction of LTP in the hippocampus needs synaptic activation of glutamate metabotropic receptors. Nature 363:347-350.

Bashir 7.I, Jane DF, Sunter DC, Watkins IC, Collingridge GL (1993b) Metabotropic glutamate receptors contribute to the induction of longterm depression in the CA1 region of the hippocampus. Eur J Pharmacol 239:265-266.

Baskys A, Malenka RC (1991) Agonists at metabotropic glutamate receptors presynaptically inhibit EPSCs in neonatal rat hippocampus. J Physiol (Lond) 444:687-701.

Baskys A, Bernstein NK, Barolet AW, Carlen PL (1990) NMDA and quisqualate reduce a Ca-dependent $\mathrm{K}^{+}$current by a protein kinasemediated mechanism. Neurosci Lett 112:76-81.

Batchelor AM, Madge DJ, Garthwaite J (1994) Synaptic activation of metabotropic glutamate receptors in the parallel fibre-Purkinje cell pathway in rat cerebellar slices. Neuroscience 63:911-915.

Baude A, Nusser Z, Roberts JDB, Mulvihill E, Mcllhinney RA, Somogyi $\mathbf{P}(1993)$ The metabotropic glutamate receptor (mGluR $1 \alpha$ ) is concentrated at perisynaptic membrane of neuronal subpopulations as detected by immunogold reaction. Neuron 11:771-787.

Bortolotto ZA, Collingridge GL (1992) Activation of glutamate metabotropic receptors induces long-term potentiation. Eur J Pharmacol 214:297-298.

Bortolotto LA, Collingridge GL (1993) Characterization of LTP induced by the activation of glutamate metabotropic receptors in area CA1 of the hippocampus. Neuropharmacology 32:1-9.

Breitwieser GE, Szabo G (1985) Uncoupling of cardiac muscarinic and $\beta$-adrenergic receptors from ion channels by a guanine nucleotide analogue. Nature 317:538-540

Breitwieser GE, Szabo G (1988) Mechanism of muscarinic receptorinduced $\mathrm{K}^{+}$channel activation as revealed by hydrolysis-resistant GTP analogues. J Gen Physiol 91:469-493.

Brown AM (1991) A cellular logic for $G$ protein-coupled ion channel pathways. FASEB J 5:2175-2179.

Brown AM (1993) Membrane-delimited cell signaling complexes: direct ion channel regulation by $\mathrm{G}$ proteins. J Membr Biol 131:93-104.

Charpak S, Gähwiler BH (1991) Glutamate mediates a slow synaptic response in hippocampal slice cultures. Proc R Soc Lond [Biol] 243: $221-226$.

Charpak S, Gähwiler BH, Do KQ, Knöpfel T (1990) Potassium conductances in hippocampal neurons blocked by excitatory amino-acids transmitters. Nature 347:765-767.

Choi D (1988) Glutamate neurotoxicity and diseases of the nervous system. Neuron 1:623-634.

Clapham DE (1994) Direct G protein activation of ion channels? Annu Rev Neurusci 17:441-464.

Codina J, Yatani A, Grenet D, Brown AM, Birnbaumer L (1987) The $\alpha$ subunit of the GTP binding protein $\mathrm{G}_{\mathrm{k}}$ opens atrial potassium channels. Science 236:442-445.

Cole AE, Nicoll RA (1984) Characterization of a slow cholinergic post-synaptic potential recorded in vitro from rat hippocampal pyramidal cells. J Physiol (Lond) 352:173-188.

Collins DR, Davies SN (1993) Co-administration of (1S, 3R)-1-aminocyclopentane-1,3-dicarboxylic acid and arachidonic acid potentiates synaptic transmission in rat hippocampal slices. Eur J Pharmacol 240:25-326.

Connor JA, Petrozzino JJ, Verselis L, Pozzo Miller LD (1994) Synaptic $\left[\mathrm{Ca}^{2+}\right]_{i}$ transients in dendrites of hippocampal CA3 pyramidal cells in the presence of ionotropic glutamate receptors antagonists: role of metabotropic receptors. Soc Neurosci Abstr 20:651.

Crépel V, Aniksztejn L, Ben-Ari Y, Hammond C (1994) Glutamate metabotropic receptors increase a $\mathrm{Ca}^{2+}$-activated non-specific cationic current in CAl hippocampal neurons. J Neurophysiol 72:1561-1569.

Curry K, Magnusson DSK, McLennan H, Peet MJ (1987) Excitation of rat hippocampal neurones by the stereoisomers of cis and trans1-amino-1,3-cyclopentane dicarboxylate. Can J Physiol Pharmacol $65: 2196-2201$. 
Desai MA, Smitl TS, Conn PJ (1992) Multiple metabotropic glutamate receptors regulate hippocampal function. Synapse 12:206-213.

Donevan SD, Rogawsky MA (1993) GYKI-52466, a 2,3-benzodiazepine, is a highly selective, noncompetitive antagonist of AMPA/kainate receptor responses. Neuron 10:51-59.

Dutar P, Nicoll RA (1988) Pre- and postsynaptic $\mathrm{GABA}_{\mathrm{B}}$ receptors in the hippocampus have different pharmacological properties. Neuron 12:585-591.

Duvoisin RM, Zhang C, Ramonell K (1995) A novel metabotropic glutamate receptor expressed in the retina and olfactory bulb. J Neurosci 15:3075-3083.

Eaton S $\Lambda$, Jane DE, Jones PL, St J Porter RHP, Pook PC-K, Sunter DC, Udvarhelyi PM, Roberts PJ, Salt E, Watkins JC (1993) Competitive antagonism at metabotropic glutamate receptors by $(S)$-4-carboxyphenylglycine and $(R, S)$ - $\alpha$-methyl-4-carboxyphenylglycine. Eur $\mathrm{J}$ Pharmacol 244:195-197.

Gähwiler BH (1981) Organotypic monolayer cultures of nervous tissue. J Neurosci Methods 4:329-342.

Gähwiler BH, Brown DA (1985) $\mathrm{GABA}_{\mathrm{B}}$-receptor-activated $\mathrm{K}^{+}$current in voltage-clamped CA3 pyramidal cells in hippocampal cultures. Proc Natl Acad Sci USA 82:1558-1562.

Gallagher JP, Zheng F (1993) Distinct subtypes of pertussis toxin-resistant metabotropic glutamate receptors at rat dorsolateral septal nucleus (DLSN) neurons. Soc Neurosci Abstr 19:470.

Gallagher JP, Zheng F, Hasuo H, Shinnick-Gallagher P (1995) Activities of rat dorsolateral septal nucleus (DLSN) neurons. Prog Neurobiol 45:373-395.

Ganong AH, Lanthorn TH, Cotman CW (1983) Kynurenic acid inhibits synaptic and acidic amino acid-induced responses in the rat hippocampus and spinal cord. Brain Res 273:170-174.

Gerber U, Sim JA, Gähwiler BH (1992) Reduction of potassium conductances mediated by metabotropic glutamate receptors in rat CA3 pyramidal cells does not require protein kinase $\mathrm{C}$ or protein kinase A. Fur J Neurnsci 4:792-797.

Gilman AG (1987) G proteins: transducers of receptor-generated signals. Annu Rev Biochem 56:615-649.

Grant SGN, O'Dell TJ, Karl KA, Stein PL, Soriano P, Kandel ER (1992) Impaired long-term potentiation, spatial learning, and hippocampal development in fyn mutant mice. Science 258:1903-1910.

Guérineau NC, Gähwiler BH, Gerber U (1994) Reduction of resting $\mathrm{K}^{-1}$ current by metabotropic glutamate and muscarinic receptors in rat CA3 cells: mediation by G-proteins. J Physiol (Lond) 474:27-33.

Guérineau NC, Bossu J-L, Gähwiler BH, Gerber U (1995) Activation of a nonselective cationic conductance by metabotropic glutamatergic and muscarinic agonists in CA3 pyramidal neurons of the rat hippocampus. J Neurosci 15:4395-4407.

Harvey J, Frenguelly B G, Sunter D C, Watkins J C, Collingridge G L (1991) The actions of $1 S, 3 R$-ACPD, a glutamate metabotropic receptor agonist, in area CA1 of rat hippocampus. Br J Pharmacol 104 75.

Hepler JR, Gilman AJ (1992) G proteins. Trends Biol Sci 17:383-387.

Hestrin S, Nicoll RA, Perkel DJ, Sah P (1990a) Analysis of excitatory synaptic action in pyramidal cells using whole-cell recording from rat hippocampal slices. J Physiol (Lond) 422:203-225.

Hestrin S, Sah P, Nicoll RA (1990b) Mechanisms generating the time course of dual component excitatory synaptic currents recorded in hippocampal slices. Neuron 5:247-253.

Hille B (1992) G protein-coupled mechanisms and nervous signaling. Neuron 9:187-195.

Honoré T, Davies SN, Drejer J, Fletcher EJ, Jacobsen P, Lodge D, Nielsen FE (1988) Quinoxalinediones: potent competitive non-NMDA glutamate receptor antagonist. Science 241:701-703.

Irving AJ, Schofield JG, Watkins JC, Sunter DC, Collingridge GL (1990) $1 S, 3 R$-ACPD stimulates and L-AP3 blocks $\mathrm{CA}^{2+}$ mobilization in rat cerebellar neurons. Eur J Pharmacol 186:363-366.

Ishida M, Agaki H, Shimamoto K, Ohfune Y, Shinozaki H (1990) A potent metabotropic glutamate receptor agonist: electrophysiological actions of a conformationally restricted glutamate analogue in the rat spinal cord and Xenopus oocytes. Brain Res 537:311-314.

Johansen TH, Drejer J, Wätjen F, Nielsen EO (1993) A novel nonNMDA receptor antagonist shows selective displacement of low affinity [ $\left.{ }^{3} \mathrm{H}\right]$ kainate binding. Eur J Pharmacol 246:195-204.

Jonas P, Major G, Sakmann B (1993) Quantal components of unitary EPSCs at the mossy fibre synapse on CA3 pyramidal cells of tat hippocampus. J Physiol (Lond) 472:615-663.
Kasof GM, Mahanty NK, Pozzo Miller LD, Curran T, Connor JA, Morgan JI (1995) Spontaneous and evoked glutamate signalling influences Fos-lacZ expression and pyramidal cell death in hippocampal slice cultures from transgenic rats. Mol Brain Res, in press.

Katz LC (1987) Local circuitry of identified projection neurons in cat visual cortex brain slices. J Neurosci 7:1223-1249.

Kauer JA, Tsien RW (1990) Intracellular recordings from pyramidal cell pairs in cultured rat hippocampal slices. Soc Neurosci Abstr 16: 145.

Keller BU, Konnerth A, Yaari Y (1991) Patch clamp analysis of excitatory synaptic currents in granule cells of rat hippocampus. J Physiol (Lond) 435:275-293.

Krogsgaard-Larsen P, Ferkany JW, Nielsen EO, Madsen U, Ebert B, Johansen JS, Diemer NH, Bruhn T, Beattie DT, Curtis DR (1991) Novel class of amino acid antagonists at non- $N$-methyl-D-aspartic acid excitatory amino acid receptors. Synthesis, in vitro and in vivo pharmacology, and neuroprotection. J Med Chem 34:123-130.

Lerma J, Paternain AV, Naranjo JR, Mellström B (1993) Functional kainate-selective glutamate receptors in cultured hippocampal neurons. Proc Natl Acad Sci USA 90:11688-11692.

Lester RA, Jahr CE (1990) Quisqualate receptor-mediated depression of calcium currents in hippocampal neurons. Neuron 4:741-749.

Linden DJ, Connor JA (1991) Participation of postsynaptic PKC in cerebellar long-term depression in culture. Science 254:1656-1659.

Linden DJ, Dickinson MH, Smeyne M, Connor JA (1991) A long-term depression of AMPA currents in cultured cerebellar Purkinje neurons. Neuron 7:81-89.

Liu YB, Disterhoft JF, Slater T (1993) Activation of metabotropic glutamate receptors induces long-term depression of GABAergic inhibition in hippocampus. J Neurophysiol 69:1000-1004.

Logothetis DE, Kurachi Y, Galper J, Neer EJ, Clapham DE (1987) The $\beta \gamma$ subunits of GTP-binding proteins activate the muscarinic $K^{+}$ channel in heart. Nature 325:321-326.

Lorente de Nó R (1934) Studies of the structure of the cerebral cortex. II. Continuation of the study of the ammonic system. J Psychol Neurol 46:113-177.

Mager R, Ferroni S, Shubert P (1995) GTP- and GDP-analogues modulate an inwardly rectifying chloride channel in cultured hippocampal neurons. Neurosci Lett 184:165-168.

Mattera R, Yatani A, Kirsch KE, Graf R, Olate J, Okaba K, Codina J, Brown AM, Birnbaumer L (1989) Recombinant $\alpha_{i-3}$ subunit of $\mathrm{G}$ protein activates $\mathrm{G}_{\mathrm{k}}$-gated $\mathrm{K}^{+}$channels. $\mathbf{J}$ Biol Chem 264:465-471.

McBain CJ, Boden P, Hill RG (1989) Rat hippocampal slices "in vitro" display spontaneous epileptiform activity following long-term organotypic culture. J Neurosci Methods 27:35-49.

McGuinness N, Anwyl R, Rowan M (1992) Trans-ACPD enhances long-term potentiation in the hippocampus. Eur J Pharmacol 197: 231-232

Miles R, Poncer JC (1993) Metabotropic glutamate receptors mediate a post-tetanic excitation of guinea pig hippocampal inhibitory neurones. J Physiol (Lond) 463:461-473.

Mody I, DeKoninck Y, Otis TS, Soltesz I (1994) Bridging the cleft at GABA synapses in the brain. Trends Neurosci 17:517-525.

Mooney R, Schumn EM, Madison DV (1993) Properties of synaptically-coupled CA3 and CA1 neurons in organotypic cultures. Soc Neurosci Abstr 19:611.

Muller D, Buchs P-A, Stoppini L (1993) Time course of synaptic development in hippocampal organotypic cultures. Dev Brain Res 71 : 93-100.

Nakajima Y, Iwakabe H, Akazawa C, Nawa H, Shigemoto R, Mizuno N. Nakanishi S (1993) Molecular characterization of a novel retinal metabotropic glutamate receptor mGluR6 with a high agonist selec tivily to L-2-amino-4-phosphonobutylate. J Biol Chem 268:1186811873.

Nakanishi S (1992) Molecular diversity of glutamate receptors and implications for brain function. Science 258:597-603.

Nicoll RA, Malenka RC, Kauer JA (1990) Functional comparison of neurotransmitter receptor subtypes in mammalian central nervous system. Physiol Rev 70:513-565.

Nusser Z, Mulvihill E, Streit P, Somogyi P (1994) Subsynaptic segregation of metabotropic and ionotropic glutamate receptors as revealed by immunogold localization. Neuroscience 61:421-427.

O'Dell TJ, Huang PL, Dawson TM, Dinerman JL, Snyder SH, Kandel ER, Fishman MC (1994) Endothelial NOS and the blockade of LTP 
by NOS inhibitors in mice lacking neuronal NOS. Science $265: 542-$ 546.

Okamoto N, Hori S, Akazawa C, Hayashi Y, Shigemoto R, Mizuno N, Nakanishi S (1994) Molecular characterization of a new metabotropic glutamate receptor mGluR7 coupled to inhibitory cyclic AMP signal transduction. J Biol Chem 269:1231-1236.

Otani S, Ben-Ari Y (1991) Metabotropic receptor-mediated long-term potentiation in rat hippocampal slices. Eur J Pharmacol 205:325-326.

Otis TS, DeKoninck Y, Mody I (1993) Characterization of synaptically elicited $\mathrm{GABA}_{13}$ responses using patch-clamp recordings in rat hippocampal slices. J Physiol (Lond) 463:391-407.

Pacelli GJ, Kelso SR (1991) Trans-ACPD reduces multiple components of synaptic transmission in the rat hippocampus. Neurosci Lett $132: 267-269$

Petrozzino JJ, Connor JA (1994) Dendritic $\mathrm{Ca}^{2+}$ accumulations and metabotropic glutamate receptor activation associated with an $\mathrm{N}$-methyl-D-aspartate receptor independent long-term potentiation in hippocampal CA1 neurons. Hippocampus 4:546-558.

Pfaffinger PJ, Martin JM, Hunter DD, Nathanson NM, Hille B (1985) GTP-binding proteins couple cardiac muscarinic receptors to a $\mathrm{K}^{+}$ channel. Nature 317:536-538.

Pfrieger FW, Gottmann K, Lux HD (1994) Kinetics of GABA ${ }_{B}$ receptor-mediated inhibition of calcium currents and cxcitatory synaptic transmission in hippocampal neurons in vitro. Neuron 12:97-107.

Pook PC-K, Sunter DC, Udvarhelyi PM, Watkins JC (1992) Evidence for presynaptic depression of monosynaptic excitation in neonatal rat motoneurones by $(1 S, 3 S)$ - and $(1 S, 3 R)$-ACPD. Exp Physiol 77:529_ 532.

Pozzo Miller LD, Petrozzino JJ, Connor JA (1993a) Metabotropic glutamate receptor responses in pyramidal neurons induced by synaptic activation of different pathways in hippocampal slice cultures. Soc Neurosci Abstr 19:272.

Pozzo Miller LD, Petrozzino JJ, Mahanty NK, Connor JA (1993b) Optical imaging of cytosolic calcium, electrophysiology, and ultrastructure in pyramidal neurons of organotypic slice cultures from rat hippocampus. Neuroimage 1:109-120.

Pozzo Miller LD, Mahanty NK, Connor JA, Landis DMD (1994a) Spontaneous pyramidal cell death in organotypic slice cultures from rat hippocampus is prevented by glutamate receptor antagonists. Neuroscience $63: 471-478$.

Pozzo Miller LD, Petrozzino JJ, Verselis L, Connor JA (1994b) Fast excitatory postsynaptic currents in hippocampal CA3 pyramidal cells in the presence of ionotropic glutamate receptor antagonists:involvement of PTX-insensitive G proteins. Soc Neurosci Abstr 20:651

Rainnie DG, Asprodini EK, Shinnick-Gallagher P (1992) Kindlinginduced long-lasting changes in synaptic transmission in the basolateral amygdala. J Neurophysiol 67:443-454.

Ross EM (1989) Signal sorting and amplification through G proteincoupled receptors. Neuron 3:141-152.

Rothman SM, Olney JW (1986) Glutamate and the pathophysiology of hypoxic-ischemic brain damage. Ann Neurol 19:105 111 .

Sahara Y, Westbrook GL (1993) Modulation of calcium currents by a metabotropic glutamate receptor involves fast and slow kinetic components in cultures hippocampal neurons. J Neurosci 13:3041-3050.

Sakaguchi T, Okada M, Kawasky K (1994) Sprouting of CA3 pyramidal neurons to the dentate gyrus in rat hippocampal organotypic cultures. Neurosci Res 20:157-164.

Salt TE, Eaton SA (1991) Excitatory actions of the metabotropic excitatory amino acid receptor agonist, trans (土)-1-amino-cyclopentane-1,3-dicarboxylate (t-ACPD) on rat thalamic neurons in vivo. Eur J Neurosci 3:1104-1111.

Schoepp DD, Conn PI (1993) Metahotropic ghutamate receptors in brain function and pathology. Trends Neurosci 14:13-20.

Schoepp DD, Johnson BJ (1989) Comparison of excitatory amino acidstimulated phosphoinositide hydrolysis and $N\left[{ }^{3} \mathrm{H}\right]$ acetylas partylglutamate binding in rat brain: selective inhibition of phosphoinositide hydrolysis by 2-amino-3-phosphonopropionate. J Neuruclien 53:273-278.

Shirasaki T, Harata N, Akaike N (1994) Metabotropic glutamate re- sponse in acutely dissociated hippocampal CA1 pyramidal neurones of the rat. J Physiol (Lond) 475:439-453.

Stone TW, Perkins MN, Collins JF, Curry K (1981) Activity of the enantiomers of 2-amino-5-phosphonovaleric acid as stereospecific antagonists of excitatory amino acids. Neuroscience 6:2249-2252.

Stoppini L, Buchs L-A, Muller D (1991) A simple method for organotypic cultures of nervous tissue. J Neurosci Methods 37:173-182.

Stratton KR, Worley PF, Baraban JB (1989) Excitation of hippocampal neurons by stimulation of glutamate $Q_{p}$ receptors. Eur J Pharmacol 173:235-237.

Stratton KR, Worley PF, Baraban JB (1990) Pharmacological characterization of phosphoinositide-linked glutamate receptor excitation of hippocampal neurons. Eur J Pharmacol 186:357-361.

Surprenant A, North RA (1988) Mechanism of synaptic inhibition by noradrenaline acting at $\alpha 2$-adrenoceptors. Proc R Soc Lond [Biol] 234:85-114.

Swartz KJ, Bean BP (1992) Inhibition of calcium channels in rat CA3 pyramidal neurons by a metabotropic glutamate receptor. J Neurosci 12:4358-4371.

Tanabe Y, Masu M, Ishii T, Shigemoto R, Nakanishi S (1992) A family of metabotropic glutamate receptors. Neuron 8:169-179.

Tanabe Y, Nomura A, Masu M, Shigemoto R, Mizuno N, Nakanishi S (1993) Signal transduction, pharmacological propertics, and expression patterns of two rat metabotropic glutamate receptors, mGluR3 and mGluR4. J Neurosci 13:1372-1378.

Tang JM, Wang J, Quandt FN, Eisenberg RS (1990) Perfusing pipettes. Pfluegers Arch 416:347-350.

Thalmann RH (1988) Evidence that guanosine triphosphate (GTP)binding proteins control a synaptic response in brain: effects of pertussis toxin and GTP $\gamma \mathrm{S}$ on the late inhibitory postsynaptic potential of hippocampal CA3 neurons. J Neurosci 8:4589-4602.

Trombley PQ, Westbrook GL (1992) L-AP4 inhibits calcium currents and synaptic transmission via a G-protein-coupled glutamate receptor. J Neurosei 12:2043-2050.

VanDongen AMJ, Codina J, Olate J, Mattera R, Joho R, Birnbaumer L, Brown AM (1988) Newly identified brain potassium channels gated by the guanine nucleotide binding protein $G_{0}$. Science 242: $1433-1437$.

Vuong TM, Chabre M, Stryer L (1984) Millisecond activation of transducin in the cyclic nucleotide cascade of vision. Nature 311:659661.

Wickman KD, Iñiguez-Lluhi JA, Davenport PA, Taussig R, Krapivinsky GB, Linder ME, Gilman AG, Clapham DE (1994) Recombinant G-protein $\beta \gamma$-subunits activate the muscarinic-gated atrial potassium channel. Nature 368:255-257.

Williams SH, Johnston D (1991) Kinetic properties of two anatomically distinct excitatory synapses in hippocampal CA3 pyramidal neurons. I Neurophysiol 66:1010-1020.

Wong EHF, Kemp JA, Priestley T, Knight AR, Woodruff GN, Iversen LL (1986) The anticonvulsant MK-801 is a potent $N$-methyl-D-aspartate antagonist. Proc Natl Acad Sci USA 83:7104-7108.

Yang X-D, Connor JA, Faber DS (1994) Weak excitation and simultaneous inhibition induce long-term depression in hippocampal CAI neurons. J Neurophysiol 71:1586-1590.

Zheng F, Gallagher JP (1992) Metabotropic glutamate receptors are required for the induction of long-term potentiation. Neuron 9:163172.

Zhou FM, Hablitz JJ (1993) Bicuculline unmasks a fast EPSP resistant to glutamatergic antagonists in rat neocortex. Soc Neurosci Abstr 19: 469.

Zimmer J, Gähwiler BH (1984) Cellular and connective organization of slice cultures of the rat hippocampus and fascia dentata. J Comp Neurol 228:432-446.

Zimmer J, Gähwiler BH (1987) Growth of hippocampal mossy fibers: a lesion and co-culture study of organotypic slice cultures. J Comp Neurol 264:1-13.

Zorumsky CF, Yamada KA, Price MT, Olney JW (1993) A benzodiazepine recognition site associated with the non-NMDA glutamate receptor. Neuron 10:61-67. 